\title{
A problemática da tutela executiva dos direitos difusos, coletivos e individuais homogêneos
}

\section{The issue of the executive protection of the diffuse, collective, homogeneous and individual rights}

\author{
Emílio Borges e Silva ${ }^{1}$
}

\begin{abstract}
Resumo
Este trabalho aborda o estudo da tutela jurisdicional em matéria de direitos coletivos, difusos e individuais homogêneos, mormente no que se reporta à sua tutela executiva, reveladora do momento essencial da proteção jurisdicional dos direitos. Toma como base de pesquisa o microssistema jurídico da tutela coletiva, composto pela Lei da Ação Civil Pública e Código de Defesa do Consumidor (com aplicação subsidiária do Código de Processo Civil), destinado a proteger os direitos metaindividuais. Ademais, discute-se acerca da ausência de um corpo legislativo próprio adequado a proteger tais direitos, consagrados no rol de direitos fundamentais pela Carta Magna de 1988. Procura demonstrar a necessidade de se criar uma nova sistemática de proteção jurisdicional coletiva liberta da normativização de perspectiva liberal individualista contida no Código de Processo Civil de 1973. Ao final, aborda-se o movimento de codificação do direito processual coletivo brasileiro, destacando as principais propostas presentes no Anteprojeto do Código Brasileiro de Processos Coletivos, além de realçar a necessidade de novas discussões para seu aprimoramento.

Palavras-chave: Direitos coletivos. Direitos fundamentais. Processo de execução. Código brasileiro de processos coletivos.
\end{abstract}

\begin{abstract}
This work concerns the study of judicial protection in matters of collective, diffuse, homogeneous and individual rights, especially as it relates to its executive protection, revealing the critical time of the judicial protection of these rights. The research is based on the collective protection of the legal microsystem, consisting of the Public Civil Action law and the Consumer Defense Code (with subsidiary application of the Civil Procedure Code) to protect the meta-individual rights. Moreover, it discusses about the absence of a legislative body which is appropriate to protect such rights, established in the list of fundamental rights by the Constitution of 1988. It seeks to demonstrate the need to create a new system of judicial protection, free of regulation of the individualistic liberal perspective included in the Civil Procedure Code of 1973. Finally, it addresses the codification movement of the collective procedure law in Brazil, highlighting the main proposals in the Draft of the Brazilian Code of Collective Processes, besides the need for further discussions to its improvement.

Keywords: Collective rights. Fundamental rights. The executive process. Brazilian code of collective processes.
\end{abstract}

${ }^{1}$ Acadêmico do $5^{\circ}$ ano do Curso de Direito da Universidade Estadual de Londrina e membro do Programa de Iniciação Científica pela mesma universidade emiliobsilva@hotmail.com 


\section{Introdução}

O mundo passou por profundas transformações ao longo dos últimos séculos e a sociedade contemporânea tem-se libertado das amarras do individualismo. A realidade socioeconômica, notadamente após a Revolução Industrial, moldou-se de tal forma que o século XX assistiu ao desenvolvimento incessante das economias de massa, na qual a tendência é o agrupamento dos indivíduos ou categorias sociais cujos direitos ou interesses possuem um ponto de convergência.

Nesse passo, as lesões aos direitos humanos passaram a alcançar dezenas, milhares ou milhões de cidadãos. Essas macrolesões passaram a exigir uma resposta do direito positivo para tornarem efetivos estes "novos direitos", uma vez que o individualismo do século XIX cedeu lugar à massificação em velocidade acelerada.

Essa evolução, contudo, não foi acompanhada com igual celeridade pelo instrumental jurídico. Os mecanismos tradicionais de acesso à justiça não foram bastantes para assegurar a defesa de todos os tipos de interesses que as manifestavam em face da nova realidade socioeconômica. Assim, acompanhando o movimento de sucumbência da filosofia liberal, as marcas individualistas que delineavam dogmas da legitimidade ad causam, coisa julgada e litispendência não eram mais suficientes para conferir efetividade aos direitos oriundos de lesões que transcendem a esfera jurídica individual.

Logo, identificou-se que há certos direitos e interesses que não pertenciam a uma única pessoa, mas a um grupo ou a uma coletividade, os quais mereceriam uma reflexão acerca da necessidade de se repensar a tutela jurisdicional desses direitos fundamentais de terceira geração.

Percebeu-se que os titulares de direitos subjetivos, mormente em uma sociedade massificada, podem não ser identificados, ou porque o direito diz respeito a toda comunidade ou porque pertence a uma coletividade indeterminável.

Por conseguinte, o presente trabalho é resultado desse reflexo da "coletivização dos direitos", à medida que procura salientar a criação dos novos institutos indispensáveis à necessidade de adaptação do ordenamento jurídico pátrio. Como se verá mais adiante, atualmente há uma tendência de que o individual não raras vezes deve ceder ao coletivo no âmbito processual, como forma de potencializar o acesso à justiça, a celeridade processual e a segurança jurídica.

A primeira parte do trabalho versará a respeito do conceito e natureza jurídica dos interesses metaindividuais e suas respectivas espécies, bem como trará as peculiaridades inerentes de cada uma.

A segunda parte cuidará das noções gerais do direito processual coletivo, princípios, fundamentos constitucionais e dos instrumentos processuais de defesa coletiva no direito brasileiro, as chamadas ações coletivas.

A terceira parte abordará a problemática do Código de Processo Civil de 1973 em relação à tutela da execução coletiva, no que concerne ao insuficiente regramento da matéria pelo direito brasileiro.

A quarta parte, por sua vez, descreverá como ocorre a execução coletiva em matéria de direitos difusos, coletivos e individuais homogêneos, segundo a atual legislação disciplinadora da matéria: Lei da Ação Civil Pública (LACP), Código de Defesa do Consumidor (CDC) e Código de Processo Civil (CPC).

Por fim, o trabalho discutirá as propostas contidas no anteprojeto do Código Brasileiro de Processos Coletivos (Anteprojeto USP), em discussão no Ministério da Justiça, no que atine à execução coletiva e o movimento pela codificação do direito processual coletivo como um todo. 


\section{Conceito e Natureza Jurídica dos Direitos Metaindividuais}

Interesse metaindividual, em sua essência, é a síntese dos interesses individuais dos membros da coletividade: "Interesses metaindividuais são direitos subjetivos de natureza indivisível, concernentes a uma coletividade de pessoas que possui uma identidade social, mas é desprovida de personalidade jurídica." (SOUZA, 2000, p. 3).

São direitos que transcendem a esfera jurídica individual e se fundem no tecido social. Ademais, dizem respeito a toda uma coletividade de indivíduos, pois excedem o conceito de interesse individual e não chega a constituir um interesse público (SILVA, 2000, p. 2).

A nomenclatura transindividual justamente denota a idéia de direitos que pertencem a um grupo, categoria ou classe de pessoas que tenham entre si um vínculo, seja de natureza jurídica ou fática.

São exemplos de interesses transindividuais os compartilhados por todas as vítimas de um produto nocivo que foi posto no mercado; ou pelos contratantes que possam estar sujeitos aos efeitos perniciosos de certo poluente que tenha sido lançado na atmosfera.

No que tange à natureza jurídica dos direitos metaindividuais, é relevante, primeiramente, mencionar que a doutrina constitucional, em regra, estabelece uma classificação histórica de evolução dos direitos fundamentais, nomeados de primeira, segunda e terceira geração ou dimensão.

Os direitos fundamentais de primeira geração traduzem o primeiro patamar de alforria do ser humano reconhecidos por uma constituição (ARAÚJO; NUNES JUNIOR, 2005, p. 115). Oriundos do modelo estatal liberal, são os direitos de defesa do indivíduo em face do Estado, onde a preocupação foi definir uma área de domínio do Poder Público simultaneamente a outra de domínio individual, a qual deveria o Administrador inteiramente respeitar ${ }^{2}$. A Declaração dos Direitos do Homem e do Cidadão, de 1789, encarta exemplos clássicos, como o direito de propriedade, liberdade e os direitos civis e políticos.

De outra sorte, os direitos fundamentais de segunda geração se pautam pela preocupação com as necessidades dos indivíduos. Logo, enquanto os de primeira geração se debruçam sobre os direitos individuais frente ao arbítrio estatal, os de segunda geração partem para a imposição de prestações positivas do Estado como forma de satisfação às necessidades inerentes à dignidade da pessoa humana. ${ }^{3}$ Constituem direitos fundamentais de segunda geração os direitos sociais, econômicos e culturais, seja na dimensão individual, seja na dimensão coletiva.

Por fim, a terceira etapa é onde estão insertos os direitos metaindividuais ou coletivos lato sensu.

Nela surge uma nova convergência de direitos, que pensam o ser humano enquanto gênero, e não se adstringem ao indivíduo ou mesmo a uma coletividade determinada (ARAÚJO; NUNES JUNIOR, 2005, p. 116).

André Ramos Tavares (2007, p. 429), em sua obra Curso de Direito Constitucional, anota: "São direitos de terceira dimensão aqueles que se caracterizam pela sua titularidade coletiva ou difusa, como o direito do consumidor e o direito ambiental. Também costumam serem denominados como direitos da solidariedade ou fraternidade."

Esse enfoque do ser humano em sua vertente relacional situa-se numa faixa intermediária entre os clássicos direitos individuais, de um lado, e o direito público, de outro.

Nesse ínterim, cumpre destacar a pesquisa pioneira de Mauro Cappelletti, na década de 70 .

\footnotetext{
2 São as chamadas "liberdades públicas negativas" ou "direitos negativos", pois exigem do Estado um comportamento de abstenção.

3 São os chamados “direitos de crença”, pois trazem a esperança de uma participação ativa do Estado.
} 
Verificara o jurista:

A concepção tradicional de processo civil não deixava espaço para a proteção dos direitos difusos. $O$ processo era visto apenas como um assunto entre duas partes, que se destinava à solução de uma controvérsia entre essas mesmas partes a respeito de seus próprios interesses individuais. Direitos que pertencessem a um grupo, ao público em geral ou a um segmento do público não se enquadravam bem nesse esquema. As regras determinantes da legitimidade, as normas de procedimento e a atuação dos juízes não eram destinadas a facilitar as demandas por interesses difusos intentadas por particulares (CAPPELLETTI, 1975, p. 49-50).

Adotando o mesmo entendimento, Antonio Gidi (1995, p. 26) ensina que "exatamente por não se constituírem na soma dos direitos individuais, os direitos superindividuais são uma categoria autônoma de direito subjetivo, cujos titulares são uma comunidade ou coletividade."

Portanto, tem-se que os direitos metaindividuais possuem uma natureza jurídica intermediária ao interesse público e ao interesse privado. Não é pública, porque a sua titularidade não pertence ao Estado e nem se confunde com o bem comum; não é privada porque não pertence a uma pessoa, isoladamente, mas um grupo, classe ou categoria de pessoas.

No direito positivo brasileiro, os interesses metaindividuais compreendem os coletivos em sentido estrito, difusos e individuais homogêneos, que serão a seguir detalhados.

\section{Objeto material do direito processual coletivo}

Pretende-se, neste ponto, delimitar quais são os direitos e interesses metaindividuais tutelados pelo direito processual coletivo, a fim de se distinguir se determinado conflito ocorrido no seio social possui natureza individual ou coletiva, bem como introduzir a distinção das respectivas tutelas jurisdicionais executivas em cada caso.

Essa conceituação ganhou corpo com a edição do Código de Defesa do Consumidor (Lei n. 8078, de 11-9-1990). O referido diploma legal adotou uma classificação baseada em três categorias: direitos metaindividuais coletivos, difusos e individuais homogêneos (art. 81, parágrafo único, I, II e III do CDC).

Dos dispositivos se nota que o legislador levou em conta três critérios para determinar esta classificação. O critério subjetivo leva em conta a aferição da titularidade do respectivo direito ou interesse material. O segundo critério, de índole objetiva, diz respeito à divisibilidade ou não do direito material. Já o terceiro critério é a origem, por intermédio da qual se busca a fonte do respectivo interesse ou direito material (GIDI, 1995, p. 22).

Ao citar o Código de Defesa do Consumidor, é preciso mencionar o comentário de Kazuo Watanabe, um dos autores do anteprojeto do diploma consumerista, a respeito da interpretação do artigo 81 e do sentido da expressão "interesses", contida no parágrafo único:

[...] Hoje, com a concepção mais larga do direito subjetivo, abrangente também do que outrora se tinha como mero 'interesse' na ótica individualista então predominante, ampliou-se o espectro da tutela jurídica e jurisdicional. Agora, é a própria Constituição Federal que, seguindo a evolução da doutrina e da jurisprudência, usa dos termos 'interesses' (art. $5^{\circ}$, LXX, b), 'direitos e interesses coletivos' (art. 129, III), como categorias amparadas pelo Direito (WATANABE, 1999, p. 718).

Em outras palavras, os termos interesses e direitos são apresentados sem distinção de significação entre eles ${ }^{4}$. Ressalte-se, ainda, que, segundo a classificação doutrinária dominante, a expressão direitos ou

4 Segundo José Carlos Barbosa Moreira (1977, p. 175): "Desde que se esteja persuadido [...] da necessidade de assegurar aos titulares proteção jurisdicional eficaz, não importará tanto, basicamente, saber a que título se lhes há de dispensar tal proteção. Afinal de contas, inexiste princípio a priori segundo o qual toda situação jurídica subjetiva que se candidate à tutela estatal por meio do processo deva obrigatoriamente exibir casta de cidadania entre direitos, no sentido rigoroso da palavra." 
interesses coletivos abrange os direitos coletivos em sentido estrito, direitos interesses difusos e os direitos ou interesses individuais homogêneos.

\section{Direitos ou interesses difusos}

Dispõe o art. 81, parágrafo único, I, da Lei n. 8078 de 1990, que os direitos ou interesses difusos são os transindividuais, de natureza indivisível, cujos titulares são pessoas indeterminadas e ligadas por circunstâncias de fato.

Por conseguinte, adotando-se os critérios anteriormente expostos, pode-se dizer que esta espécie de direitos coletivos caracterizase pela indivisibilidade quanto ao objeto, indeterminabilidade dos sujeitos e pela origem comum baseada por circunstâncias fáticas.

Cabe citar um exemplo: caso uma determinada empresa divulgue por grande rede de televisão propaganda enganosa que induza em erro os consumidores que assistam a ela, o interesse em retirar do ar essa publicidade pode qualificado como difuso.

Observe-se que o objeto é indivisível, porque toda a coletividade, indistintamente, estará exposta aos seus efeitos nocivos: o risco afeta a todos ou não afeta ninguém.

Veja-se também que os sujeitos são indeterminados ou indetermináveis, de maneira que todas as pessoas que poderiam, podem ou poderão entrar em contato com a publicidade enganosa serão os titulares do direito. Assim, a indeterminabilidade do sujeito é marcada pela impossibilidade de objetivamente individualizar os titulares da pretensão jurídica a ser deduzida.

Por fim, note-se que a relação que une os possíveis titulares do direito material é fática, e não jurídica. A relação que agrega os indivíduos no pólo ativo é fática, qual seja, o fato de estarem potencialmente expostos à hipótese danosa, visto que não há nenhum vínculo jurídico entre eles e o causador responsável pelos danos (GONÇALVES, 2007, p. 7).

Celso Antônio Pacheco Fiorillo (1995, p. 92) ressalta, no texto constitucional, alguns dos dispositivos que traduzem direitos difusos. Seriam, dentre outros, os seguintes: art. $5^{\circ}$, caput-proibição do preconceito de origem, cor e raça; art. 170, III - a função social da propriedade; art. $7^{\circ}$, XXII redução de riscos inerentes ao trabalho por meio de normas de saúde, higiene e segurança; arts. 205, 215, 216 e 219, dentre outros - educação, cultura, tecnologia; arts. 196 e 200 - o sistema único de saúde; art. 225 - política urbana e meio ambiente; art. $1^{\circ}, \mathrm{IV}-$ os valores sociais do trabalho e da livre iniciativa; arts. $5^{\circ}$, XXXII, 170, V, e 48, do Ato das Disposições Constitucionais Transitórias - proteção e defesa do consumidor; arts. 226 a 230 - a família, a criança, o adolescente, e o idoso; arts. 220 a 224 a comunicação social.

Dessarte, cabe finalizar afirmar que, com fulcro no art. $5^{\circ}$, parágrafo $2^{\circ}$ da Constituição Federal, o rol de direitos difusos é exemplificativo, pois assume feições de cláusula aberta a ser preenchida em cada caso concreto, considerando os valores sociais envolvidos no litígio.

No âmbito da justiça do trabalho, Renato Saraiva elenca as seguintes situações concretas de existência de interesses e direitos difusos a serem tutelados por meio do manejo da competente ação civil pública: greve em atividade essenciais, com o não-atendimento da necessidade inadiáveis da comunidade, contratação sem concurso público, discriminação de trabalhadores em razão de sexo, idade, raça ou deficiência e a utilização de trabalho escravo.

\section{Direitos ou interesses coletivos em sentido estrito}

$\mathrm{O}$ art. 81, parágrafo único, II, do Código de Defesa do Consumidor, conceitua direitos coletivos como os transindividuais de natureza indivisível de 
que seja titular um grupo, categoria ou classe de pessoas ligadas entre si ou com a parte contrária por uma relação jurídica base.

Portanto, de antemão tem-se que o principal traço distintivo dos direitos coletivos em sentido estrito, em relação aos direitos difusos, repousa na origem (vínculo jurídico e não de fato) e na determinabilidade dos sujeitos titulares (critério subjetivo):

É apenas analisando o aspecto origem que a diferença entre os direitos difusos e os coletivos mais nitidamente ressalta. Enquanto nos direitos difusos as pessoas que compõem a comunidade titular do direito não são ligadas por nenhum vínculo jurídico prévio, mas por meras circunstâncias de fato, nos direitos coletivos as pessoas que compõem a coletividade titular do direito são ligadas por uma prévia relação jurídica-base que mantinha entre si ou com a parte contrária (GIDI, 1995, p. 24).

Assim, vale dizer que nesta categoria de direitos a relação jurídica base preexiste à lesão ou ameaça de lesão do interesse pertencente ao grupo, classe ou categoria de pessoas. Assim acrescenta Watanabe (1999, p. 721-722):

Nos interesses ou direitos 'difusos', a sua natureza indivisível e a inexistência de relação jurídica base não possibilitam, como já ficou visto, a determinação dos titulares. [...] Mas, a relação jurídica base que nos interessa, na fixação dos conceitos em estudo, é aquela da qual é derivado o interesse tutelado, portanto interesses que guarda relação mais imediata e próxima com a lesão ou ameaça de lesão.

Por outro lado, o ponto conceitual de similitude entre as citadas categorias reside no aspecto objetivo, eis que os direitos coletivos em sentido estrito também são transindividuais, indivisíveis e indistinguíveis na forma dos difusos. Isso significa que a fruição do bem por parte de um membro da coletividade implica necessariamente sua fruição por parte de todos, assim como sua negação para um representa a negação para todos (GRINOVER,
2000, p. 11).

Poder-se-ia dizer que o direito dos alunos de determinada escola de ter assegurada a mesma qualidade de ensino em determinado curso ou o interesse de consorciados de ver declarada nulidade de uma cláusula abusiva inserida no contrato de adesão pela empresa de consórcios são exemplos clássicos de direitos coletivos.

Em síntese, os interesses difusos e coletivos se assemelham pela indivisibilidade do objeto, o que os dá feição de direitos superindividuais, ao passo que os direitos individuais homogêneos, como se verá adiante, são titularizados por pessoas determinadas, sendo considerados direitos superindividuais apenas no plano processual pelo tratamento coletivo diferenciado que recebem.

\section{Direitos ou interesses individuais homogêneos}

Este grupo traduz, segundo o art. 81, parágrafo único, III, do Código de Defesa do Consumidor, aqueles direitos decorrentes de uma origem comum, o que acaba por possibilitar a tutela coletiva.

Pelo aspecto subjetivo, tem-se que os titulares são pessoas perfeitamente individualizadas ou determináveis sem nenhuma dificuldade. A título ilustrativo, imagine-se um veículo fabricado defeituosamente e posto no mercado de consumo. Nesse caso, os potenciais adquirentes desse veículo são indeterminados, mas as vítimas de acidente são determinadas.

No que tange ao âmbito objetivo, são estes direitos sem dúvida divisíveis e distinguíveis, de modo que, no exemplo do parágrafo anterior, cada uma das vítimas poderia propor sua ação individual de indenização e o juiz acolher algumas e não outras.

Leciona o ilustre doutrinador Hugo Nigro Mazzilli (2008, p. 55) acerca das diferenças dos direitos individuais homogêneos em relação aos direitos coletivos em sentido estrito:

$$
\text { Por sua vez, os interesses coletivos e os }
$$


interesses individuais homogêneos têm também um ponto de contato: ambos reúnem grupo, categoria ou classe de pessoas determináveis; contudo, distinguem-se quanto à divisibilidade do interesse: só os interesses individuais homogêneos são divisíveis, supondo uma origem comum. Exemplifiquemos com uma ação coletiva que visa à nulificação de cláusula abusiva em contrato de adesão. No caso, a sentença de procedência não irá conferir um bem divisível aos integrantes do grupo lesado. $\mathrm{O}$ interesse em ver reconhecida a ilegalidade da cláusula é compartilhado pelos integrantes do grupo de forma não quantificável e, portanto, indivisível: a ilegalidade da cláusula não será maior para quem tenha dois ou mais contratos em vez de apenas um: a ilegalidade será igual para todos eles (interesse coletivo, em sentido estrito).

Sob o aspecto de sua origem, direitos individuais homogêneos e direitos difusos guardam similitude, em razão de ambas as categorias nascerem ligadas a um evento fático de circunstância comum. Portanto, eles diferem dos direitos coletivos em sentido estrito, onde a relação jurídica preexistente é congênita.

É imperioso ressaltar que o traço marcante dos direitos individuais homogêneos é o seu caráter acidentalmente coletivo ${ }^{5}$, eis que em sua essência são individuais (divisíveis), mas podem receber tratamento processual coletivo por intermédio de uma única ação em vista da homogeneidade de suas origens fáticas comuns. Vale dizer, são direitos individuais homogeneamente considerados.

Seriam, assim, uma categoria que representa uma ficção criada pelo direito positivo brasileiro, com o objetivo exclusivo de proteção coletiva de direitos individuais, com dimensão coletiva, atendendo previsão expressa de tutela na lei (GIDI, 1995, p. 30).

Com efeito, não são raros os julgados nos quais não se tem entendido a correta distinção entre estes direitos em relação aos coletivos em sentido estrito e difusos. ${ }^{6}$

Um exemplo de notável utilidade didática é o Resp. 933002 do RJ, proferido pela $2^{\text {a }}$ Turma do Egrégio Superior Tribunal de Justiça, cujo relator foi o Ministro Castro Meira. Nele se discute a legitimidade do Ministério Público para propor ação civil pública baseada em interesses coletivos ou difusos para garantir a oferta de ensino noturno regular.

No caso, a ação civil pública foi ajuizada pelo MP objetivando a manutenção do curso de ensino médio no período noturno no Colégio de Pedro II (Unidade de São Cristóvão - RJ), pois esse período teria sido ilegalmente suprimido pelo diretor da unidade. Segundo o Ministério Público, o que se busca exatamente (mas não apenas) é a defesa de direitos difusos, no sentido de que o direito tutelado

\footnotetext{
5 É o que esclarece Rodolfo de Camargo Mancuso (1997, p. 39): “[...] os ‘difusos' e os 'coletivos em sentido estrito’ são 'essencialmente coletivos', ao passo que os 'individuais homogêneos' recebem tratamento processual coletivo pelo uniformizado como se exteriorizam, assim parecendo ao legislador que sua tutela judicial seria mais adequada e eficaz". No mesmo sentido, segue trecho esclarecedor de precedente do Superior Tribunal de Justiça: "Diante disso, é razoável afirmar que os interesses difusos e coletivos jamais se individualizam, por ser de sua essência a indivisibilidade, o que impõe sempre a execução coletiva iniciada pelas entidades indicadas no art. 82 do CDC, salvo outros legitimados. Já os interesses individuais homogêneos são divisíveis por natureza e ganham tratamento processual coletivo por simples questão de política judiciária, sendo inegável a legitimidade ativa das vítimas para a liquidação e execução.” (REsp 880.385-SP, Rel. Min. Nancy Andrighi, julgado em 2/9/2008.

6 Nesse sentido, Gregório Assagra de Almeida (2003, p. 493) comenta precedente do STF: "Consta da motivação do acórdão do STF, rel. Min. Maurício Corrêa, que reconheceu a legitimidade ativa do Ministério Público, para o ajuizamento de ACP, com a finalidade de alcançar a observância, pelas escolas particulares, das normas de reajustes das mensalidades escolares estabelecidas pelo Conselho Estadual de Educação, que os interesses defendidos o recurso seriam homogêneos pela origem comum, por serem decorrentes de uma mesma origem, qual seja, a cobrança das mensalidades escolares de forma abusiva (RE 163.231-3/SP, $\mathrm{j}$. 26.2.1997). Portanto, não tendo a ACP, na hipótese, buscado a reparação na esfera individual de cada um dos respectivos alunos, e se verificando que o que se pretendia era uma decisão que beneficiasse indistintamente todos os alunos, concluiu-se que o direito no caso era coletivo em sentido restrito e não individual homogêneo.
} 
é o direito fundamental à educação, consubstanciado na garantia de manutenção do turno da noite no Colégio de Pedro II - unidade São Cristóvão.

Em primeira instância, a ação foi extinta sem resolução do mérito, em função da alegada ilegitimidade ativa do MP, em razão do direito discutido supostamente ser individual homogêneo ${ }^{7}$. $\mathrm{O}$ órgão ministerial apelou, alegando que a manutenção do curso noturno naquela unidade não é questão afeta somente aos interesses dos alunos, já matriculados, mas de futuros alunos, coletividade impassível de ser individualizada ou identificada.

A decisão foi reformada pelo TRF da $2^{a}$ Região e novamente discutida no Superior Tribunal de Justiça, que manteve a decisão proferida pelo tribunal, sob os seguintes fundamentos:

ADMINISTRATIVO. AÇÃO CIVIL PÚBLICA. MANUTENÇÃO DO TURNO NOTURNO EM COLÉGIO FEDERAL. DIREITO COLETIVO E DIFUSO. LEGITIMIDADE ATIVA DO MINISTÉRIO PÚBLICO FEDERAL.

1) Estudar no turno da noite na Unidade São Cristóvão do Colégio Pedro II é um direito titularizável por qualquer atual ou futuro aluno de tal Unidade do Colégio Pedro II, que lá estude, ou venha a estudar, no turno noturno. Direito titularizável, destarte, por pessoas indeterminadas e indetermináveis, o que é o caso dos futuros alunos (direito difuso), e por pessoas determinadas, ou seja, por uma 'classe de pessoas ligadas entre si ou com a parte contrária por uma relação jurídica base', o que é o caso dos atuais alunos do turno noturno (direito coletivo).

2) Exsurge clara, outrossim, a sua 'natureza indivisível', na medida em que não podem ser compartilhados individualmente entre seus titulares, ou seja, atendido o direito de um aluno a estudar no turno noturno, será atendido o de todos. Desse modo, não se pode afirmar com precisão a quem pertencem, nem em que medida quantitativa são compartilhados, o que por si só já afasta a sua caracterização como direito individual homogêneo, categoria em que o titular é perfeitamente identificável e cujo objeto é divisível e cindível.

3) Trata-se, pois, de direito coletivo e difuso, conforme a titularidade

considerada, nos termos dos incisos I e II, do art. 81, da Lei 8.078/90, o que atrai a legitimidade ativa do Ministério Público Federal, in casu, exvi do art.1 ${ }^{\circ}$, inciso V, da Lei 7.347/85. (Resp. 933.002 - STJ) (BRASIL, 2007).

O que se perquiriu, in casu, é se a manutenção ou não do turno escolar noturno na unidade São Cristóvão do Colégio Pedro II constitui 'direito individual homogêneo', ou 'direito coletivo e difuso', e prevaleceu o entendimento pela legitimidade do MP para propor a ação civil pública.

Portanto, o caso ilustra bem como a verificação do direito coletivo no caso concreto depende de criteriosa análise quanto à (in)divisibilidade do objeto e (in)determinabilidade dos sujeitos, o que por vezes é tormentosa.

Em conclusão, pode-se afirmar que o interesse em comento é social, a despeito do interesse de cada vítima ser ressarcida pelos danos que tenha sofrido. ${ }^{8}$ Nesses casos, a propositura da ação coletiva terá como fito a imposição da obrigação de indenizar os prejudicados pelo ato lesivo, objetivo este de interesse coletivo. Somente depois vem o interesse individual de cada pessoa em ser ressarcida naquele quantum em que foi prejudicada.

Sendo assim, o que se tutela nos direitos individuais homogêneos, em decorrência de

\footnotetext{
7 Segundo o art. 139, III, o Ministério Público não tem legitimidade para propor ação civil pública versando sobre direitos individuais homogêneos.

8 "O direito ou interesse individual puro não é objeto do direito processual coletivo. Mesmo no caso dos direitos ou interesses individuais homogêneos, não há que se falar em tutela de direito individual puro, mas de vários direitos ou interesses individuais que recebem, pela origem comum que gera a homogeneidade entre eles, a tutela jurisdicional coletiva - tanto que são considerados como direitos ou interesses acidentalmente coletivos (ALMEIDA, 2003, p. 495).
} 
serem processualmente coletivos, é o interesse globalmente considerado, justificado para evitar a proliferação de demandas individuais, a dispersão das vítimas e a insegurança causada por decisões judiciais contraditórias versando sobre a mesma matéria.

\section{Direito Processual Coletivo}

\section{Noções introdutórias}

Antes de ser iniciado o estudo específico da execução coletiva, faz-se necessário que se defina o sentido de direito processual coletivo. Como não se trata de um conceito completamente sedimentado, alguns autores utilizam a denominação tutela jurisdicional coletiva (VIGLIAR, 1998, p. 15), ação coletiva (GIDI, 1995, p. 15) ou demanda coletiva (WATANABE, 1992, p. 185).

Essa divergência terminológica decorre do fato de que, não obstante existam inúmeros dispositivos legais e princípios específicos que disciplinam a matéria, ainda não há uma posição clara quanto à autonomia deste ramo da ciência jurídica.

O objetivo do trabalho não é entrar no mérito dessa questão, mas não há como deixar de destacar o entendimento adotado pelo promotor Gregório Assagra de Almeida, que, em sua brilhante obra na busca pela sistematização do processo coletivo, afirmou que o direito processual coletivo tem verdadeira natureza constitucional e é uma espécie de direito processual constitucional:

[...] ramo do direito processual que possui natureza de direito processual-constitucionalsocial, cujo conjunto de normas e princípios a ele pertencente visa disciplinar a ação coletiva, o processo coletivo, de forma a tutelar, no plano abstrato, a no plano concreto, pretensões coletivas em sentido lato, decorrentes de conflitos coletivos ocorridos no dia-a-dia da conflituosidade social (ALMEIDA, 2003, p. 22).

Ao reconhecer este novo ramo do direito processual, instaura-se, portanto, uma classificação processual tripartite baseada no texto constitucional, dividida em direito processual penal, direito processual civil e direito processual coletivo.

Partindo desta premissa, afigura-se de extrema relevância definir os contornos do que se entende por ação coletiva, ou seja, o instrumento de que se vale o direito processual coletivo para tutelar os direitos metaindividuais.

Segundo Antônio Gidi (1995, p.15), dizer, tãosomente, que ação coletiva é aquela proposta em defesa de direitos difusos, coletivos ou individuais homogêneos é incorrer em grave equívoco:

É possível a propositura de ação em defesa de tais direitos que seja, em sua estrutura, uma ação individual. Há que pensar no exemplo em que todos os associados de uma pequena empresa de assistência médica ajuízem, em litisconsórcio ativo, uma ação contra aumentos ilegais de mensalidade. O direito não deixa de ser coletivo (CDC, art. 81, parágrafo único, I), ainda que tutelado por uma ação individual.

Complementando este raciocínio, Kazuo Watanabe (1993, p. 195) assevera que:

[...] a natureza verdadeiramente coletiva da demanda depende não somente da legitimação ativa para a ação e da natureza dos interesses ou direitos nela vinculados, como também da causa de pedir invocada e do tipo e abrangência do provimento jurisdicional postulado, e ainda da relação de adequação entre esses elementos objetivos da ação e a lagitimação ad causam passiva.

Já Rodolfo de Camargo Mancuso (1994a, p. 25) considera uma ação coletiva quando algum nível do universo coletivo será atingido no momento em que transitar em julgado a decisão que a acolhe, espraiando, assim, seus efeitos.

Agregando essas noções, pode-se dizer que ação coletiva é aquela ação proposta por um legitimado autônomo, em nome próprio, mas em defesa de um direito coletivamente considerado em sua causa de pedir, cuja imutabilidade da decisão irá alcançar 
uma comunidade ou coletividade.

Delimitadas essas noções propedêuticas, convém agora apontar o fundamento constitucional das ações coletivas e sua relação com os direitos fundamentais.

\section{Enquadramento constitucional das ações coletivas e os direitos fundamentais}

$\mathrm{O}$ art. $1^{\mathrm{o}}$ da Constituição Federal consagra a dignidade da pessoa humana como valor constitucional supremo e núcleo axiológico informador de toda a interpretação constitucional.

Nesse diapasão, a Carta Magna busca promover e proteger a dignidade da pessoa humana por intermédio dos direitos fundamentais.

Ademais, o principal objetivo do Estado Democrático de Direito não é apenas justificar os direitos sociais como direitos humanos, mas sim garanti-los (BOBBIO, 1992, p. 18). Portanto, inspirado nessa assertiva, o legislador constituinte brasileiro revelou especial preocupação no que tange ao arcabouço de efetivação dos direitos coletivos.

E não poderia ser diferente, eis que, conforme pontua Zulmar Antonio Fachin, a transindividualidade é característica dos direitos fundamentais:

Há direitos fundamentais cuja titularidade não pertence apenas a uma, mas a centenas, milhares ou milhões de pessoas. $\mathrm{O}$ direito ao meio ambiente ecologicamente equilibrado e o direito à paz são exemplos de direitos fundamentais transindividuais. Esses direitos, que se afirmaram a partir da segunda metade do século XX, constituem uma categoria diversa, gerando a noção de direitos difusos e coletivos (FACHIN, 2008, p. 215).

E as ações coletivas constituem importante instrumento de acesso à justiça, direito fundamental consagrado no art. $5^{\circ}, \mathrm{XXXV}$, pois permitem a universalização da demanda, isto é, sua tutela é capaz, a uma só vez, de atender a uma totalidade de indivíduos que se encontram numa mesma situação jurídica verificada no caso concreto.

Por conseguinte, o sistema jurídico brasileiro já consagra de forma expressa a tutela jurídico-material dos direitos de massa, inserindo-os inclusive como integrantes do rol de direitos fundamentais (Título II, Capítulo I, art. $5^{\circ}$ da Constituição Federal de 1988). É o que se infere dos seguintes dispositivos constitucionais: art. $1^{\circ}$; art. $5^{\circ}, \mathrm{XXXV}, \mathrm{LXX}, \mathrm{LXXI}$, LXXIII; art. 14, $\S 10$ e 11 , art. $37, \S 4^{\circ}, 114, \S 2^{\circ}$, art. 129 , III, e $\S 1^{\circ}$; art. 102, I, a, $\S \S 1^{\circ}$ e $2^{\circ}$, art. 103 , $\S \S 1^{\circ}, 2^{\circ}$ e $3^{\circ}, 125, \S 2^{\circ}$, entre outros.

José Carlos Barbosa Moreira, escrevendo sobre as Ações Coletivas na Constituição Federal de 1988, refere-se a duas formas de expressão da tutela coletiva:

[...] o fenômeno das Ações Coletivas, que nessa Constituição assume dimensões até então desconhecidas do Direito Constitucional brasileiro, se manifesta, na verdade, sob duas formas. De um lado, temos figuras processuais específicas de ações coletivas: o mandado de segurança coletivo, previsto no art. $5^{\circ}$, LXIX; ação popular, prevista no mesmo art. $5^{\circ}$, LXXIII; e a ação civil pública, objeto da disposição no art. 129 , III, e de seu $\S 1^{\circ}$. De outro lado, temos também a manifestação desse fenômeno em termos genéricos, por assim dizer, para qualquer ação, como se infere do art. $5^{\circ}$, XXI, que legitima entidades associativas, mediante autorização expressa, a litigar, em juízo, por direitos de seus associados; e ainda no art. $8^{\circ}$, VI, que cuida da possibilidade de os sindicatos a litigarem em juízo, em prol dos direitos e interesses das categorias profissionais que representam direitos e interesses gerais ou mesmo individuais [...] (MOREIRA, 1991, p. 189-190).

Essess dispositivos são manifestações do fenômeno da constitucionalização do processo, que tem por finalidade essencial conferir guarida e dignidade constitucional de institutos garantidores da efetividade do acesso individual e coletivo ao Poder Judiciário. É o que nos ensina Elton Venturi:

Assim, para que se possa aludir a uma 
verdadeira sistemática do processo coletivo, comprometida com a efetividade da prestação da tutela jurisdicional dos direitos metaindividuais, indispensável é a proposição de um método que permite extrair do texto constitucional os valores fundamentais a que se dirige a instrumentalidade do processo coletivo no âmbito do "Estado Social Democrático de Direito", onde o acesso à Justiça deixa de ser mero postulado pragmático para representar a efetividade do sistema processual na busca da realização da ordem social, econômica e política (VENTURI, 2000, p. 19-20).

Dessa forma, o diploma constitucional passou a reger expressamente a coletivização do processo por meio de instrumentos judiciais de proteção do meio ambiente, patrimônio público e social e interesses metaindividuais (difusos, coletivos e individuais homogêneos), como a ação civil pública, o mandado de segurança coletivo, a ação popular e o mandado de injunção coletivo. Da mesma forma, houve a ampliação da legitimação ad causam para a promoção das ações coletivas reconhecida ao Ministério Público, aos corpos intermediários (associações civis, sindicais etc) e ao próprio Estado e suas descentralizações administrativas (LEITE, 2009, p. 40).

\section{Princípios específicos do direito processual} coletivo brasileiro

Passa-se a elencar, sem a pretensão de esgotar a matéria, alguns princípios informadores do microssistema jurisdicional coletivo brasileiro que têm como ponto de interface o interesse social.

Princípio do interesse jurisdicional no conhecimento do mérito do processo coletivo

Este princípio traduz a idéia de que o Poder
Judiciário, amparado pelo sistema constitucional atual (art. $5^{\circ}, \mathrm{XXXV}$ da CF), deve exercer ativamente o papel fundamental de apreciar as grandes causas sociais relativas ao meio ambiente, patrimônio público, proteção do consumidor, etc. Além de apreciar, cabe-lhe também promover a resolução do mérito do conflito coletivo.

A luz desse princípio, o Judiciário deverá optar pela flexibilização dos requisitos de admissibilidade processual, a fim de optar pelo conhecimento do comando jurídico esperado socialmente, em vez de procurar questão processual para extinguir o feito sem apreciação de mérito (ALMEIDA, 2003, p. 572).

Portanto, enquanto na ação individual o exame das condições da ação devem dotar de rigidez, no processo coletivo esta análise deve ser mitigada, pois o que importa é a discussão sobre o direito material coletivo lato sensu. ${ }^{9}$

Princípio da máxima prioridade jurisdicional da tutela coletiva

Este princípio sustenta a posição de prevalência de tramitação e julgamento das demandas coletivas, por tratarem de interesses sociais relevantes. Por conseqüência, evita-se a proliferação indesejada de demandas individuais e decisões conflitantes versando sobre a mesma matéria.

Gregório Assagra sintetiza o espírito albergado pelo princípio:

[...] Não seria nem um pouco razoável que o Poder Judiciário não desse prioridade às tutelas jurisdicionais coletivas, pois é no julgamento desses conflitos coletivos que ele terá o condão de dirimir, em um único processo e em uma única decisão, um grande conflito coletivo ou vários conflitos individuais entrelaçados por

\footnotetext{
9 Exemplifica Gregório Assagra de Almeida: "No processo individual não se pode permitir que outrem venha a juízo, em nome próprio, defender direito alheio. Esse raciocínio, todavia, não pode ser aplicado com esse rigor ao processo coletivo. Efetivamente, como o direito difuso, por exemplo, tem como titulares pessoas indetermináveis e indeterminadas, dificilmente haverá alguém que se disponha a defendê-lo em juízo e, ainda que assim o fizesse, o sistema não autoriza o particular individualmente considerado a ajuizar ação na defesa desse mesmo direito difuso" (ALMEIDA, 2003, prefácio).
} 
uma homogeneidade de fato ou de direito [...] (ALMEIDA, 2003, p. 573).

Pode-se dizer, em arremate, que este postulado deriva do princípio da supremacia do interesse público sobre o privado, pressuposto básico de existência de qualquer sociedade.

Princípio da disponibilidade motivada da ação coletiva

Este princípio está esculpido no art. $5^{\circ}, \S 3^{\circ}$ da Lei da Ação Civil Pública e traduz a idéia de vedar a desistência ou abandono imotivado da ação coletiva, velando pelo interesse social deduzido na demanda.

Dessa forma, o controle do abandono ou desistência infundada da causa é feito precipuamente pelo Ministério Público ou pelos outros legitimados ativos da ação coletiva, de maneira que qualquer destes entes poderá assumir o polo ativo da relação jurídica processual e prosseguir o feito.

Princípio da presunção da legitimidade ad causam ativa pela afirmação do direito

Conforme estabelece o art. 127, caput, e art. 129, III, ambos da Lei Maior, o Ministério Público é instituição permanente, essencial à função jurisdicional do Estado, incumbindo-lhe a defesa da ordem jurídica, do regime democrático e dos interesses sociais e individuais indisponíveis. Sendo assim, o constituinte originário conferiu ao Ministério Público o papel de principal defensor e legitimado para o ajuizamento das ações coletivas.

Portanto, por se tratar de verdadeira legitimidade institucional, basta a afirmação do direito social ou coletivo para que se presuma a legitimidade constitucional do Ministério Público, sendo despiciendo questionar a real titularidade do direito coletivo defendido para se aferir a legitimidade.

\section{Princípio da Não-taxatividade da ação coletiva}

Pelo mecanismo de acesso coletivo à justiça instaurado pela ordem constitucional vigente, a rigor do que prevêem os arts. $5^{\circ}, \mathrm{XXXV}, 129$, III, da CF, qualquer direito coletivo poderá ser objeto de ação coletiva.

Trata-se um princípio de fundo hermenêutico, uma vez que sustenta a não-taxatividade, para efeitos de ajuizamento, do rol de direitos elencados no art. 129, III, da Lei Maior, por exemplo. Ou seja, qualquer direito coletivo em sentido amplo que possa ser enquadrado no rol exemplificativo do artigo poderá ser tutelado por intermédio das ações coletivas, desde que a escolha processual produza a tutela adequada para os fins almejados.

Com base também nessa assertiva, é possível afirmar que limitações impostas pelo judiciário ou legislativo infraconstitucional ao exercício da tutela de direitos coletivos são notadamente inconstitucionais. ${ }^{10}$ (ALMEIDA, 2003, p. 575)

A título exemplificativo, é plenamente possível uma ação monitória coletiva com base em um termo de ajustamento de conduta firmado junto ao réu que desmatou uma larga região florestal. Este pacto, caso não esteja assinado por ambos transatores, poderá ser objeto de ação monitória perante o judiciário.

Princípio do máximo benefício da tutela jurisdicional coletiva

Como dito alhures, este princípio deriva da tentativa de se evitar a proliferação de excessivas demandas individuais baseadas numa mesma causa de pedir.

${ }^{10}$ Flagrantemente inconstitucional é o parágrafo único do art. $1^{\circ}$ da Lei n. 7347 de 1985 , acrescentado pelo art. $6^{\circ}$ da Medida Provisória n. 2.102-27, de 26-1-2001 (DOU, 27 de jan. 2001), e reproduzido pela atual Medida Provisória n. 2180-35, de 24-8-2001, que dispõe: "Não será cabível ação civil pública para veicular pretensões que envolvam tributos, contribuições previdenciárias, o Fundo de Garantia do Tempo de Serviço - FGTS ou outros fundos de natureza institucional cujos beneficiários podem ser individualmente determinados." (ALMEIDA, 2003, p. 575) 
A tutela jurisdicional coletiva neste ponto pode atender de forma mais célere e efetiva o acesso ao direito material. Dessa maneira, por este princípio, há uma extensão in utilibus, ou em benefício, da imutabilidade do comando jurisdicional de procedência da ação coletiva a todos os membros de determinada classe ou categoria de indivíduos ligados determinada ou indeterminadamente à lide por circunstâncias de fato ou de direito.

Para que fique mais claro, basta consultar o art. 103 , em seu $\$ 3^{\circ}$ e $\S 4^{\circ}$, no Código de Defesa do Consumidor. Com base nele, a coisa julgada coletiva procedente beneficia a todas as vítimas inseridas no pólo ativo da demanda (é transporte in utilibus da coisa julgada coletiva), de modo que um possível julgado improcedente não prejudica a interposição de uma nova ação indenizatória proposta individualmente. Em outras palavras, os efeitos favoráveis da tutela coletiva são estendidos a todos, e os prejudiciais não afetam o direito de ação individual, expressando a máxima efetividade da tutela jurisdicional coletiva.

Princípio da máxima efetividade do processo coletivo

Traduz a orientação de que processo efetivo é aquele que não dispensa diligências para que seja alcançada a verdade real, sobretudo por envolver relevantes interesses sociais.

É preciso destacar, como expressões legais desse princípio, o art. 83 do Código de Defesa do Consumidor, em sua combinação com o art. 21 da Lei de Ação Civil Pública. Segundo eles, o intérprete deverá valer-se de todos os meios necessários, eficazes e legítimos para que o processo coletivo seja realmente efetivo.

Com efeito, há uma maior iniciativa instrutória do juiz nas demandas coletivas, de modo a não permanecer inerte e como mitigação do princípio dispositivo:
Ademais, nas demandas coletivas, o próprio papel do magistrado modifica-se, enquanto cabe a ele a decisão a respeito de conflitos de massa, por isso mesmo de índole política. Não há mais espaço, no processo moderno, para o chamado "juiz neutro" - expressão com que frequentemente se mascarava a figura do juiz não comprometido com as instâncias sociais -, motivo pelo qual todas as leis processuais têm investido o julgador de maiores poder de impulso (GRINOVER, 2000, p. 81-2).

Assim, só para exemplificar, ao juiz é dada a possibilidade de conceder liminar, com fulcro no artigo 12 da Lei n. 7347 de 1985. Também é possível atribuir antecipação de tutela (art. 84, § $3^{\circ}$ da Lei 8078 de 1990) ou utilizar as medidas de apoio previstas no art. $84, \S 5^{\circ}$ da Lei n. 8078 de 1990 ou do Código de Processo Civil, tendente à tutela de obrigações específicas.

Princípio da máxima amplitude da tutela jurisdicional coletiva

Em decorrência do princípio anterior, a máxima amplitude da tutela jurisdicional coletiva preconiza que são admitidos todos os procedimentos, provimentos e tipos de ação que propiciem a adequada tutela do direito coletivo pleiteado.

Dessa forma, são cabíveis ações de conhecimento de toda natureza (declaratória, constitutiva, condenatória ou mandamental), ações de execução e ações cautelares.

Neste ponto, cumpre frisar a hipótese de antecipação da tutela jurisdicional no Processo Coletivo de Execução com base no art. 83 do Código de Defesa do Consumidor, art. 21 da Lei da Ação Civil Pública e art. 66 da Lei 8884 de 1964 (execução judicial das decisões do Conselho Administrativo de Defesa Econômica). 
Princípio da obrigatoriedade da execução coletiva pelo ministério público:

Este princípio encontra guarida expressa no art. 15 da Lei da Ação Civil Pública e no art. 16 da Lei n. 4717 de 1965, a Lei da Ação Popular, e tem por escopo básico atribuir ao Ministério Público a legitimidade ativa subsidiária e o poder-dever de promover a execução coletiva em caso de desídia de outro ente ou pessoa legitimada ativa.

\section{Princípio da participação no processo coletivo ${ }^{11}$ :}

No processo individual clássico, a participação das partes democraticamente com a fim de descoberta da verdade se dá por meio do contraditório: é a participação popular de maneira a legitimar as decisões judiciais. No processo coletivo, a participação democrática não se opera tão somente no contraditório, mas principalmente no momento de ajuizamento da ação coletiva, uma vez que os colegitimados adequados, ao exercitarem o direito de ação, agem em defesa dos direitos coletivos da sociedade.

Logo, diz-se que enquanto no processo individual a participação das partes se dá no processo, internamente, nas ações coletivas a participação se dá pelo processo (a partir do ajuizamento).

\section{Execução Coletiva e a Problemática Implantada pelo Código de Processo Civil de 1973}

Neste tópico, será abordada a questão levantada na introdução do trabalho acerca da falta de corpo legislativo próprio e a insuficiência do modelo individual-liberalista implantado pelo Código de Processo Civil de 1973 para a tutela executiva dos direitos coletivos. Nesse sentido, leciona Gregório
Assagra de Almeida:

Ocorre que o Código Civil de 1916, elaborado no final do século XIX e início do século XX, foi inspirado em uma filosofia liberal individualista, vindo a disciplinar, tão-somente, conflitos interindividuais. Até mesmo o Código Civil de 2002 não rompe totalmente esse paradigma, tanto que não reservou um capítulo sequer para tratar dos direitos massificados. O CPC/73 foi constituído para ser instrumento de resolução das lides surgidas das relações jurídicas materiais disciplinadas pelo CC/1916, tratando-se de Diploma processual pautado por uma concepção liberal individualista. Portanto, a filosofia que constituiu o $\mathrm{CPC} / 73$ não é compatível com o fenômeno denominado de coletivização do processo. Em razão disso, foram criadas formas próprias e específicas de tutela jurisdicional coletiva, visando justamente resolver os conflitos coletivos em relação aos quais o CPC não se constituía adequado (ALMEIDA, 2008.)

É oportuno dizer, então, que o Código de Processo Civil de 1973 foi concebido com o escopo de solucionar lides decorrentes de relações jurídicas materiais disciplinadas pelo Código Civil de 1916.

A luz desta reflexão, é possível mencionar alguns dispositivos que consagram essa visão liberal individualista. $\mathrm{O}$ art. $3^{\circ}$ do $\mathrm{CPC}$, ao dispor que para propor e contestar uma ação é preciso demonstração de interesse e legitimidade, dá a entender a necessidade de demonstração de interesse pessoal, de índole sempre individual. $\mathrm{O}$ art. $6^{\circ}$ prescreve que a ninguém é dado o direito de defender em nome próprio direito alheio, salvo quando autorizado por lei. ${ }^{12}$

Da mesma forma, os arts. 264 e 294 do CPC estatuem sobre a estabilização da causa de pedir e do pedido (perpetuatio libeli), o que é incompatível com a exigência de proteção ampla e integral dos direitos e interesses metaindividuais. O art. 293 prescreve

${ }_{11}$ Sobre este princípio ver Gajardoni (2009).

${ }^{12}$ Consagrou-se aqui a clássica orientação bipartida sobre a legitimidade (em ordinária e extraordinária), modelos esses fechados e incompatíveis com a necessidade de defesa ampla a irrestrita em juízo dos interesses e direitos massificados (ALMEIDA, 2007, p. 50). 
que o juiz deverá interpretar restritivamente, o que também não é razoável em razão de que nos direitos massificados o pedido deve ser interpretado de forma aberta e flexível. Outro ponto a ser citado é o art. 267, II e III, de forma que a desídia das partes ou do legitimado coletivo não pode ocasionar a extinção do processo em prejuízo de direitos sociais relevantes.

Por tudo isso, conclui-se que o CPC não é diploma adequado para dispor sobre os processos coletivos, sobremaneira em virtude de que muitos dispositivos citados confrontarem-se com os princípios expostos no tópico anterior. Ademais, conclui-se também sua aplicabilidade em sede de processos coletivos é subsidiária e limitada, de forma a respeitar a prioridade do microssistema da tutela jurisdicional coletiva (LACP e CDC) e não colocar em risco a proteção dos direitos e interesses massificados.

Isso fez gerar, naturalmente, dificuldades e prejuízos à efetividade dos direitos ou interesses massificados. ${ }^{13}$

No que concerne à temática específica do trabalho, mesmo as últimas reformas processuais, que atingiram pontualmente o rito executivo do código, não prestaram qualquer preocupação relativa à problemática da execução de interesses massificados, os quais permanecem timidamente tratados em diplomas legais esparsos.

Neste ínterim, o Código de Defesa do Consumidor chega até a conferir um direcionamento à tutela executiva dos direitos individuais homogêneos (arts. 95 a 100). No que concerne aos direitos difusos e coletivos em sentido estrito, a carência normativa ainda é mais patente. A lei 7347 de 1985, a Lei de Ação Civil Pública, disciplina a matéria basicamente em dois artigos (arts. 13 e 15). Já a da Ação Popular $\mathrm{n}^{\mathrm{o}} 4.717 / 65$ somente dedica dois artigos ao tema da execução da sentença proferida no processo instaurado pela ação popular (arts. 14 e 16). Por fim, a Lei de Improbidade Administrativa (Lei no 8.429/92) dispõe acerca da matéria em um só de seus artigos (art. 18).

Assim sendo, releva assentar que a crise resultante do vácuo legal de disciplina do tema é ainda mais evidente, à medida que persiste a dependência estrutural e procedimental em relação ao Código de Processo Civil, diploma orientado preponderantemente para a satisfação de créditos oriundos de demandas individuais.

A propósito, convém salientar que o Código de Processo Civil será aplicado de forma subsidiária e condicionada ao processo de execução coletiva. Deste teor é o ensinamento de Elton Venturi (2000, p. 160):

$\mathrm{Na}$ aplicação subsidiária do $\mathrm{CPC}$ ao processo coletivo, devemos investigar acerca da idoneidade da transposição pura e simples de dispositivos idealizados originariamente para instrumentalizar pretensões individuais, a fim de não se afrontar princípios informativos ou fundamentais do processo coletivo.

Veja-se que tanto a Lei deAção Civil Pública, em seu artigo 19, quanto o Código de Defesa do Consumidor, no artigo 90, prevêem esta aplicabilidade subsidiária. Contudo, para que isso ocorra é preciso haver uma compatibilidade necessária com a principiologia do direito coletivo, exposta anteriormente, sobretudo em razão do relevante interesse social envolvidos nas questões massificadas. ${ }^{14}$

Portanto, em face desta lacuna no sistema jurídico brasileiro quanto a um corpo próprio para reger a execução coletiva, nada mais certo de

\footnotetext{
${ }^{13}$ Isto porque os institutos ortodoxos do processo civil não podem ser aplicados aos direitos transindividuais, porquanto o processo civil foi idealizado como ciência em meados do século passado, notavelmente influenciado pelos princípios liberais do individualismo que caracterizaram as grandes codificações do século XIX. Ao pensar, por exemplo, em legitimação para a causa como instituto ligado ao direito material individual a ser discutido em juízo, não se pode ter esse mesmo enfoque quando se fala de direitos difusos cujo titular do direito material é indeterminável (NERY JÚNIOR, 2004, p. 156).

${ }^{14}$ A interpretação restritiva do pedido (art. 293 do CPC), a estabilização da demanda a partir da decisão saneadora (art. 264, parágrafo único, do CPC), a responsabilidade processual objetiva (arts. 571 e 811 do CPC), entre inúmeras outras disposições do CPC, são diretrizes processuais que, em razão de inibirem e colocarem em risco a proteção dos direitos massificados, não são compatíveis, substancialmente, com a principiologia que rege o direito processual coletivo (ALMEIDA, 2003, p. 583-584).
} 
que propugnar por um procedimento específico, adequado às aspirações da efetividade dos direitos difusos, coletivos e individuais homogêneos (VENTURI, 2000, p. 90).

Atualmente, encontra-se em trâmite no Ministério da Justiça um anteprojeto do Código Brasileiro de Processos Coletivos, justamente com a proposta de regulamentar a tutela jurisdicional coletiva no país, o qual será estudado no último capítulo deste trabalho.

\section{Execução Coletiva Relativa aos Direitos Difusos E Coletivos}

Passa-se agora a analisar a tutela executiva quanto aos direitos difusos e coletivos em sentido estrito, os quais possuem regramento executório semelhante em virtude da indivisibilidade de seus objetos.

O procedimento executório alicerça-se na Lei da Ação Civil Pública e, no que lhe for compatível, aproveita-se o Código de Defesa do Consumidor e subsidiariamente o Código de Processo Civil.

A despeito do vácuo legislativo, que tem dificultado a efetivação desses direitos com base nos procedimentos executivos do CPC, insta tecer algumas considerações reflexivas acerca da matéria.

A coisa julgada em matéria de direitos difusos está disciplinada no art. 103, I do CDC. Em razão desse dispositivo, a coisa julgada provocará situações a serem tratadas distintamente.

Se o pedido da ação coletiva for atendido, operase a coisa julgada em favor de toda a coletividade que pode se socorrer do julgado para viabilizar indenização individual.

Havendo rejeição do pedido por insuficiência de provas, não há coisa julgada para nenhum legitimado, nem extraordinário nem ordinário, podendo ingressar o mesmo legitimado que anteriormente ajuizou a ação, outro legitimado extraordinário ou o individual, obviamente, produzindo prova nova.
E, em caso de improcedência quanto ao mérito da ação, os efeitos da coisa julgada são extensíveis aos legitimados da ação coletiva, ressalvando-se, no entanto, os direitos individuais que poderão ser buscados através da ação própria.

Este entendimento é corroborado pelo art. 103, parágrafo $1^{\circ}$, do $\mathrm{CDC}$, que determina " $\S 1^{\circ}$ Os efeitos da coisa julgada previstos nos incisos I e II não prejudicarão interesses e direitos individuais dos integrantes da coletividade, do grupo, categoria ou classe."

A coisa julgada em matéria de direitos coletivos obedece às mesmas regras válidas para os direitos difusos, com o lembrete de que a coisa julgada atingirá apenas o grupo, categoria ou classe com vínculo jurídico comum, não havendo a extensão vislumbrada no caso dos direitos difusos.

É indispensável citar o art. 104 do CDC, que deve ser interpretado conjuntamente com o art. 103, parágrafo $3^{\circ}$, do mesmo diploma legal:

Art. 104. As ações coletivas, previstas nos incisos I e II e do parágrafo único do art. 81, não induzem litispendência para as ações individuais, mas os efeitos da coisa julgada erga omnes ou ultra partes a que aludem os incisos II e III do artigo anterior não beneficiarão os autores das ações individuais, se não for requerida sua suspensão no prazo de trinta dias, a contar da ciência nos autos do ajuizamento da ação coletiva

\section{$[\ldots]$}

Art. $103 \S 3^{\circ}$ Os efeitos da coisa julgada de que cuida o art. 16, combinado com o art. 13 da Lei ${ }^{\circ}$ 7.347, de 24 de julho de 1985, não prejudicarão as ações de indenização por danos pessoalmente sofridos, propostas individualmente ou na forma prevista neste código, mas, se procedente o pedido, beneficiarão as vítimas e seus sucessores, que poderão proceder à liquidação e à execução, nos termos dos arts. 96 a 99 (BRASIL, 1990).

$\mathrm{O}$ texto procura excluir o instituto da litispendência entre as ações coletivas que tratam de direitos difusos e coletivos e aquelas propostas pelos particulares na busca dos direitos individuais. 
O legislador conferiu duas hipóteses: se o particular decidir prosseguir com ação individual, não sofrerá os efeitos da coisa julgada coletiva, ainda que favoráveis; se optar pela suspensão do processo dentro do prazo legal, a coisa julgada coletiva se procedente o beneficiará e, se improcedente, em nada afetará sua ação individual.

A execução coletiva dos direitos difusos ou coletivos em sentido estrito poderá ser provisória ou definitiva, inteligência do art. 14 da LACP.

Do aludido dispositivo, extrai-se a exegese de que, em regra, os recursos das decisões proferidas em Ações Civis Públicas serão recebidos apenas no efeito devolutivo, autorizando a possibilidade da execução provisória de sentença (art. 588 do CPC).

Já no que concerne à legitimidade ativa do processo executivo, aplica-se a orientação prevista no art. $5^{\circ}$ da LACP em conjunto com o art. 82 do CDC:

Art. 5o Têm legitimidade para propor a ação principal e a ação cautelar: I - o Ministério Público; II - a Defensoria Pública; III - a União, os Estados, o Distrito Federal e os Municípios; IV - a autarquia, empresa pública, fundação ou sociedade de economia mista; V - a associação que, concomitantemente: a) esteja constituída há pelo menos 1 (um) ano nos termos da lei civil; b) inclua, entre suas finalidades institucionais, a proteção ao meio ambiente, ao consumidor, à ordem econômica, à livre concorrência ou ao patrimônio artístico, estético, histórico, turístico e paisagístico (BRASIL, 1985).

Art. 82. Para os fins do art. 81, parágrafo único, são legitimados concorrentemente:

I - o Ministério Público,

II - a União, os Estados, os Municípios e o Distrito Federal;

III - as entidades e órgãos da Administração Pública, direta ou indireta, ainda que sem personalidade jurídica, especificamente destinados à defesa dos interesses e direitos protegidos por este código;

IV - as associações legalmente constituídas há pelo menos um ano e que incluam entre seus fins institucionais a defesa dos interesses e direitos protegidos por este código, dispensada a autorização assemblear (BRASIL, 1990)

A iniciativa do processo de execução compete, por conseguinte, concorrente e autonomamente aos indicados pela LACP e CDC, uma vez que em virtude da própria lei são somente esses os legitimados para as ações coletivas (VENTURI, 2000, p. 104).

Ademais, é relevante observar que o art. $15 \mathrm{da}$ LACP determina a obrigatoriedade de instauração do processo de execução das ações coletivas pelo Ministério Público quando decorridos 60 dias do trânsito em julgado de sentença condenatória sem manifestação do ente originalmente presente na causa. ${ }^{15}$

Quanto aos títulos executivos coletivos, é importante ressaltar o entendimento de Elton Venturi (2000, p. 97):

A imposição da obrigação de reparar dano coletivamente causado tanto pode estar formalizada em título executivo judicial (sentença condenatória em ação coletiva), como extrajudicial (através do compromisso de ajustamento previsto no $\S 6^{\circ}$ do art. $5^{\circ}$ da LACP), sendo que ambas as espécies predispõemse, em sua essência, a constituir obrigação de pagar quantia em dinheiro não propriamente ao detentor do título (um dos entes legitimados do art. 82 do (DC), mas a um fundo coletivo.

Quantoàsegundaocorrência, admite-se, no direito pátrio, a possibilidade de que os órgãos públicos legitimados pela legislação (art. $5^{\circ}$ LACP e art. 82 do $\mathrm{CDC}$ ) tomem compromissos administrativos do

\footnotetext{
${ }^{15}$ Nas ações coletivas, de lege ferenda, sugere-se a inclusão de dispositivo de imponha a iniciativa executiva ao próprio juiz do processo de conhecimento, caso transcorrido o prazo aludido pela LACP, art. 15, sem a iniciativa dos co-legitimados do art. 82 do CDC (VENTURI, 2000, p. 106).
} 
causador do dano para que ajustem sua conduta às exigências legais, conferindo aos respectivos termos a qualidade de título executivo extrajudicial (MAZZILLI, 2008, p. 351). O ilustre doutrinador ainda acrescenta: "Há mais de uma década em vigor o compromisso de ajustamento no direito brasileiro, é ele usado diariamente, nos milhares de comarcas do país, com o endosso jurisprudencial e doutrinário, ora de forma expressa, ora implícita" (MAZZILLI, 2008, p. 355).

Vale dizer, ainda, que a execução nesta hipótese de títulos executivos extrajudiciais segue, diante da falta de corpo legislativo específico, as disposições do Livro II do CPC, a depender do tipo de obrigação a ser executada: de fazer ou não fazer, o procedimento é do art. 632 e seguintes do CPC; de dar quantia certa, art. 646 e seguintes do CPC e obrigações de dar coisa certa ou incerta, art. $621 \mathrm{e}$ seguintes do CPC.

Retornando ao campo dos títulos executivos judiciais, passa-se à abordagem do processo de liquidação da sentença.

Por evidente, o tema é dos mais angustiantes, mormente quando se presta a avaliar quanto vale um bem jurídico coletivamente lesado, isto é, quanto teria importado a extensão e profundidade da lesão:

O juiz deverá pautar-se em critérios de prudência e razoabilidade na quantificação dos valores ${ }^{16}$.

Quanto à legitimidade, normalmente a iniciativa da liquidação será do próprio legitimado que atuou no processo de conhecimento, nada impedindo a atuação de outro co-legitimado ou as vítimas e sucessores.

Uma vez estando a execução amparada em título executivo judicial líquido e superada a fase de liquidação, passa-se então ao processo executivo para efetivamente atribuir ao credor o direito constante no título executivo.

Tomando-se em consideração a finalidade da tutela executiva, a extinção da execução somente poderia ter lugar ante à satisfação do crédito do exequente. Logo, a tutela executiva dos direitos difusos e coletivos só pode ser considerada como efetivamente finda quando proporciona aos seus titulares (ainda que indeterminados) a prestação específica da obrigação ou seu equivalente correspondente em pecúnia.

Neste ponto, impende dizer que a conversão da obrigação específica em perdas e danos no caso dos direitos difusos somente poderá ocorrer se for impossível o cumprimento da obrigação específica:

Os direitos difusos são substancialmente indisponíveis e, por isso, não cabe ao autor a faculdade de optar, a seu bel prazer, pela conversão da obrigação específica em perdas e danos. A reparação do dano deve guiar-se pelo princípio da maior coincidência possível entre o direito e sua realização (ALMEIDA, 2008).

Dessa forma, tomando-se o caso de danos ambientais fixados judicialmente, o juiz deverá realizar o acompanhamento do cumprimento das obrigações específicas pelos órgãos ambientais, por meio de relatórios técnicos periódicos e outras medidas.

Não sendo possível a satisfação específica do direito lesado, impõe-se, subsidiariamente, a sua conversão em perdas e danos, e o rito executório seguirá, em regra, o procedimento previsto no art. 475, alíneas I e seguintes do CPC.

Apurado o valor, este será revertido para o fundo de direito difusos ou coletivos, federal, ou estadual,

\footnotetext{
${ }^{16}$ A mensuração da extensão de dano ambiental, por vezes, torna-se extremamente difícil, pois as hipóteses como a de derramamento de óleo no mar, causando lesões à fauna e flora do litoral, em evidente prejuízo ao turismo local e ao trabalho dos pescadores da região, ou mesmo do lançamento de resíduos tóxicos à atmosfera, requerem, para que se consiga alcançar o propósito da reparação integral do bem transindividual lesado, uma maior ou menor cognição por parte do magistrado a respeito de certas condições do próprio obrigado (VENTURI, 2000, p. 102).
} 
criado pelo art. 13 da LACP $:{ }^{17}$

Tratando-se da tutela de direitos difusos e coletivos, a indeterminação dos indivíduos efetivamente lesados pela conduta danosa é, diversamente do ocorrido quando da lesão de afeta direitos individuais homogêneos, regra. Em função disto, a LACP resolveu destinar o montante recolhido a partir das condenações obtidas nas ações coletivas a fundos federais ou estaduais, que se responsabilizam pela gestão a aplicação da verba com finalidades consentâneas à espécie de lesão ocasionada (VENTURI, 2000, p. 114).

Nesse ínterim, imagine-se uma empresa poluente condenada a ressarcir os danos causados ao meio ambiente. Se a ação versar exclusivamente a respeito de interesse difuso ou coletivo, a indenização reverterá a Fundos geridos por conselhos estaduais e federais, cuja composição compreende necessariamente representantes da comunidade e do Ministério Público, devendo destinar os recursos arrecadados à reconstituição dos bens respectivamente lesados ${ }^{18}$.

É o que dispõe o art. $7^{\circ}$ do Decreto 1.306/1994, o qual, ao regulamentar o Fundo de Defesa dos Direitos Difusos, estabelece que a aplicação dos recursos arrecadados deve guardar correlação com a natureza do dano causado, sempre que possível visando à reparação específica do mesmo.

Hugo Nigro Mazzilli aduz que tal regra permite a adoção de soluções inovadoras e imaginativas: ante à destruição de bem de valor artístico, a verba indenizatória poderia ser utilizada na reconstituição, manutenção ou conservação de outras obras de arte, ou para a conservação de museus ou lugares onde elas se encontrem; diante da eliminação de animais em vias de extinção, o montante pecuniário seria destinado a criar a condições que favoreçam a procriação dos animais em seu habitat (MAZZILLI, 2008, p. 276-277).

Em nível federal, o fundo é disciplinado pela Lei 9008 de 1995. Na esfera estadual, também há a faculdade de serem criados fundos com o mesmo intuito, para os quais devem ser canalizados os recursos advindos de condenações no âmbito da justiça dos respectivos estados à reparação de danos metaindividuais ${ }^{19}$.

De outro giro, faz-se necessário lembrar que, antes da vigência do $\mathrm{CDC}$, não era possível a destinação da parcela do montante reparatório obtido em ação de defesa de direito genuinamente difuso a pessoas individualmente consideradas. Vale dizer, mesmo que um indivíduo determinado pudesse demonstrar uma lesão à sua esfera patrimonial decorrente de dano a um direito difuso, ainda assim a destinação da condenação iria in totum aos Fundos antes referidos.

Em função do disposto no art. 103, parágrafo $3^{\circ}$ do $\mathrm{CDC}$, houve a inovação para admitir a possibilidade de ressarcimento de pretensões indenizatórias a título individual, antes da integralização da quantia ao Fundo:

Indiscutível hoje a (interpretação) de que é possível que os consumidores, em sendo procedente a ação, venham a proceder à liquidação pelos prejuízos individuais sofridos e executá-los; e, se necessário, que venham a receber (total ou parcialmente) a sua parte, do numerário mesmo já recolhido ao Fundo, por

\footnotetext{
${ }^{17}$ Conforme leciona Paulo Affonso Leme Machado (1999, p. 100), a solução inovadora encontrada pela LACP encontra precedentes no direito comparado. De fato, países como Holanda, EUA, Japão e França conferem semelhante forma de destinação às verbas oriundas de condenações impostas àqueles que tenham lesado direitos difusos.

${ }^{18}$ Há casos em que esta reparação revela-se de difícil concretização, sobretudo quando a lesão ocasiona danos irreparáveis. Nesse sentido: "Nada seria capaz de reconstituir a obra de arte destruída, nem de restaurar a rocha que aformoseava a paisagem; inexiste, ademais, prestação pecuniária que logre compensar adequadamente o dano, insuscetível de medida por padrões econômicos" (MOREIRA, 1984, p. 102).

${ }^{19}$ Em relação à criação de qualquer espécie de Fundo, a Constituição Federal impõe prévia autorização legislativa (art. 167, IV). Suprido tal requisito, a instituição e regulamentação do Fundo a que se refere a LACP, art. 13, é plenamente viável (como já ocorre no Estado de São Paulo).
} 
determinação judicial (é esta a interpretação que decorre do Código de Proteção e Defesa do Consumidor, à luz do art. 99) (ALVIM et al., 1991, p.476-477).

A regra também aproveita àqueles particulares, autores de ações individuais e que tenham solicitado a sua suspensão, na forma do art. 104 do $\mathrm{CDC}^{20}$, que poderão requerer a liquidação dos danos que tenham sofrido, sem prejuízo da liquidação coletiva do valor destinado ao fundo, a ser realizado na ação civil pública.

Elucidando a questão, Marcus Vinicius Rios Gonçalves exemplifica:

Imagine-se uma ação civil pública em que se postule a condenação de uma empresa poluente a ressarcir ao fundo de reconstituição aos bens lesados os danos causados à coletividade pela deposição de dejetos em rio que corta determinada região, e a alguns moradores ribeirinhos os prejuízos que sofreram em decorrência de doenças que tenham contraído pelo consumo de água contaminada. A sentença poderá condenar o réu a pagar uma indenização ao fundo, pela ofensa ao direito difuso de proteção ao meio ambiente, e a pagar a indenização às vítimas. Trata-se de duas indenizações diferentes: a primeira tem por fim reparar os danos aos bens indivisivelmente considerados; e a segunda, ressarcir a lesão sofrida. Se o patrimônio do réu não for suficiente para arcar com as duas indenizações, será aplicável o disposto no art. 99 do CDC (GONÇALVES, 2007, p. 129-130).

Assim, trouxe o CDC significativa inovação à LACP, ao prever que indenizações pelos prejuízos individuais resultantes do mesmo evento danoso terão preferência em relação ao pagamento ao Fundo.

\section{Execução Coletiva dos Direitos Individuais Homogêneos}

Os direitos individuais homogêneos, segundo já explicitado, possuem uma natureza específica que os qualifica como acidentalmente coletivos. E, por conseqüência, seguem um rito executório próprio disciplinado pelo CDC:

Diferentemente do ocorrido no âmbito das ações coletivas para a tutela dos direitos genuinamente transindividuais, nas quais se pretende que a sentença condenatória já imponha, para além da obrigação de reparar o dano, a fixação definitiva do montante indenizatório que se destinará ao Fundo para recomposição do direito violado, a pretensão deduzida na ação coletiva que visa a tutelar direitos individuais homogêneos, quando condenatória, diz respeito somente à fixação genérica do dever de ressarcir (VENTURI, 2000, p. 125).

Essa sistemática da sentença condenatória genérica está expressamente positivada no art. 95 do CDC. Suas razões devem-se ao fato de que a demanda coletiva traduz, por vezes, milhares pretensões indenizatórias perfeitamente individualizáveis, podendo comportar diversificados nexos causais que, por conseqüência, desembocam em indenizações específicas ao patrimônio do lesado.

Nesse sentido, esclarece a professora Ada Pellegrini Grinover (1995, p. 555): "Em sentido processual, o significado da sentença condenatória genérica reporta-se ao tratamento coletivo emprestado ao bem jurídico tutelado que, até o momento dos processos de liquidação e execução da sentença, é concebido como se fosse indivisível."

Logo, o tratamento coletivo da ação que trata de direitos individuais homogêneos se dá somente até a fixação judicial do dever genérico de ressarcir. Em momento posterior, a discussão do quantum debeatur

\footnotetext{
${ }^{20}$ Art. 104. As ações coletivas, previstas nos incisos I e II e do parágrafo único do art. 81, não induzem litispendência para as ações individuais, mas os efeitos da coisa julgada erga omnes ou ultra partes a que aludem os incisos II e III do artigo anterior não beneficiarão os autores das ações individuais, se não for requerida sua suspensão no prazo de trinta dias, a contar da ciência nos autos do ajuizamento da ação coletiva.
} 
será referente aos particulares individualmente considerados em suas lesões após suas respectivas habilitações no processo.

Impõe-se informar, ainda, que para que se possa proferir sentença condenatória genérica ${ }^{21}$ não se faz necessária a prova inequívoca da existência do dano, mas sim um juízo de verossimilhança que justifique a posterior liquidação individual dos danos causados.

Uma vez superada a fase da fixação genérica do dever indenizatório, passa-se ao processo de liquidação. Como a sistemática implantada pelo art. 95 do CDC é sensivelmente distinta daquela tradicionalmente prevista no modelo de lides individuais do CPC, Cândido Dinamarco (1997, p. 26) chegou a conceituá-la de "liquidação sui generis", sendo para o referido processualista "mais que uma liquidação."

A alcunha se justifica, uma vez que mais do que fixar a quantia a ser paga pelo devedor, deverá o juízo apurar em relação ao habilitado se houve lesão de ordem patrimonial ou moral que guarde nexo com o dever indenizatório imposto genericamente na sentença. Em verdade, é uma modalidade de liquidação que enseja a abertura da ampla cognição jurisdicional. É o que anota Flávio Luiz Yarshell (1997, p. 161): “O objeto de liquidação da sentença condenatória genérica ora versada inclui, no intuito de quantificar-se os danos sofridos individualmente pelos lesados, a demonstração do nexo causal entre os danos experimentados e a responsabilização imposta na sentença."

No que se refere à legitimidade, a liquidação poderá ser individual, promovida pela vítima ou seus sucessores, ou coletiva, intenta pelos legitimados do art. 82 do CDC, nos termos do art. 97 do aludido diploma legal. Assim, o sistema brasileiro estabeleceu a legitimação individual para a liquidação dos danos ocasionados aos direitos individuais homogêneos, bem como a legitimação dos entes coletivos para a liquidação dos danos globais e residuais, cujos valores calculados serão revertidos ao Fundo criado pelo art. 13 da LACP.

Quanto ao processo de habilitação dos legitimados, a primeira questão diz respeito à divulgação da sentença condenatória genérica, pois o conhecimento da mesma deve ser levado àqueles indivíduos que, ao menos potencialmente, foram atingidos em suas esferas patrimoniais ou morais pelo fato cuja responsabilidade foi imputada ao devedor na sentença condenatória genérica.

$\mathrm{O}$ art. 94 do CDC impõe a cientificação do decreto condenatório pela via de editais quando da propositura da ação coletiva ${ }^{22}$.

No que atine às formalidades do procedimento de habilitação, não fornece o CDC maiores esclarecimentos. Devem os interessados, por conseguinte, habilitarem-se em procedimento semelhante àquele previsto no Direito do Trabalho em ações de cumprimento de sentença coletiva, conforme determina o art. 872 da CLT $^{23}$. Na seara laboral, a sentença coletiva proferida em dissídio coletivo necessita, por vezes, de reclamações individualizadas (ações de cumprimento) que servem à execução do comando judicial.

${ }^{21}$ Logo se vê que o fato de a condenação ser genérica não significa que a sentença não seja certa, ou precisa. A certeza é condição essencial do julgamento, devendo o comando da sentença estabelecer claramente os direitos e obrigações, de modo que seja possível executá-la (GRINOVER, 1995, p. 555).

${ }^{22}$ Importante ainda dizer que "o Ministério Público tem por dever diligenciar para que não se torne inócua a própria demanda coletiva de classe em função do desconhecimento, por parte dos componentes desta, da existência e dos termos de condenação" (VENTURI, 2000, p. 135).

23 Art. 872 - Celebrado o acordo, ou transitada em julgado a decisão, seguir-se-á o seu cumprimento, sob as penas estabelecidas neste Título. Parágrafo único - Quando os empregadores deixarem de satisfazer o pagamento de salários, na conformidade da decisão proferida, poderão os empregados ou seus sindicatos, independentes de outorga de poderes de seus associados, juntando certidão de tal decisão, apresentar reclamação à Junta ou Juízo competente, observado o processo previsto no Capítulo II deste Título, sendo vedado, porém, questionar sobre a matéria de fato e de direito já apreciada na decisão. 
Analogicamente, tal como os empregados na ação de cumprimento, os legitimados para a liquidação dos danos aos direitos individuais homogêneos deverão apresentar a certidão da sentença genérica perante o juízo competente, a fim de propiciar uma cognição suficiente para a execução do título judicial devido.

O microssistema consumerista dispõe em seu art. $100^{24}$ que a habilitação dos interessados deve ocorrer no interregno de até um ano do trânsito em julgado da sentença condenatória genérica.

Esse prazo, contudo, não é decadencial ou prescricional, de maneira que apenas serve de parâmetro para autorizar que os entes dos art. 82 movam a competente quantificação da indenização global e residual em face da inércia ou pequeno número de habilitados. Nesse sentido, Arruda Alvim atesta em sua obra que "mesmo depois do prazo de um ano, poderão as vítimas e sucessores vir a se habilitar, mas circunscrever-se-ão à apuração do seu direito, sem que essa habilitação venha a alterar a legitimidade dos indicados no art. 82" (ALVIM et al., 1991, p. 446).

O procedimento de liquidação deverá ser necessariamente por artigos (art. 475-E CPC) ${ }^{25}$, em razão da necessidade de se alegar e provar fato novo para determinar-se o valor da condenação: "Mesmo que a vítima, por exemplo, pretenda exclusivamente a fixação de dano moral ('puro'), ainda assim está descartada uma liquidação por arbitramento, pois sempre haverá fato nobo a ser provado e, portanto, não há como fugir da hipótese retratada pelo art. 475-E do CPC" (YARSHELL, 1997, p. 162).
A diferença em relação ao procedimento de demandas individuais é que, enquanto nesta a cognição restringe-se a fato que não tenha sido objeto de apreciação no processo de conhecimento, nas demandas de direitos individuais homogêneos a liquidação deve versar precisamente sobre a existência e extensão de danos individualizados ${ }^{26}$.

Vê-se, por tudo, que o procedimento de liquidação ora analisado possui efetivamente um mérito a ser decidido, ensejando instrução probatória a fim de se verificar a relação de causalidade entre a situação vivenciada pelo liquidante e os fundamentos da sentença condenatória genérica e a existência de efetivo dano que justifique a imposição de ressarcimento.

Superada a fase de liquidação individual dos habilitados, é plenamente cabível a execução provisória da sentença condenatória e liquidada, ainda que pendente recurso da sentença de liquidação desprovido de efeitos suspensivos, nos termos do CPC e art. 14 da $\mathrm{LACP}^{27}$ :

Assim os indivíduos beneficiados pela sentença condenatória genérica, após obterem a respectiva quantificação do que lhe é devido pelo demandado, ou propõem de pronto a competente ação de execução, mesmo que pendente recurso desprovido de efeito suspensivo, submetendose ás regras da execução provisória do $\mathrm{CPC}$, ou aguardam o trânsito em julgado da sentença, propondo a execução definitiva, uma vez que aquela não mais poderá sofrer alterações (VENTURI, 2000, p. 151).

Já em relação à execução coletiva propriamente dita, ou seja, aquela prevista no art. 100 do CDC

\footnotetext{
${ }^{24}$ Art. 100. Decorrido o prazo de um ano sem habilitação de interessados em número compatível com a gravidade do dano, poderão os legitimados do art. 82 promover a liquidação e execução da indenização devida.

${ }^{25}$ Art. 475-E. Far-se-á a liquidação por artigos, quando, para determinar o valor da condenação, houver necessidade de alegar e provar fato novo.

${ }^{26}$ Exemplificando tal tarefa, Rodoldo de Carmago Mancuso (1994b, p. 116) cita a liquidação por artigos de sentença que condenou laboratório a indenizar os prejuízos de quem ingeriu medicamento nocivo à saúde humana, onde incumbirá ao liquidante "provar seu enquadramento no universo de consumidores a que se endereça o julgado, isto é: 1) que consumia tal produto, sendo, pois, um dos prejudicados; 2) o dano e sua extensão, isto é, em quanto importou o prejuízo.

${ }^{27}$ Nesse sentido: "Nas ações coletivas, contrariando a regra geral em matéria de efeitos nos quais são recebidos os recursos nas lides individuais, o recursos são recebidos, salvo exceções, no efeito meramente devolutivo.” (VENTURI, 2000, p. 150).
} 
e proposta pelos legitimados do art. 82 do mesmo diploma legal, é pertinente a análise do fenômeno denominado fluid recovery (reparação fluida).

Trata-se de instituto, cuja nomenclatura é originária das class actions norte-americanas, disposto no art. 100 do $\mathrm{CDC}$, que traduz a preocupação do legislador no caso em que se apura lesão a direitos individuais homogêneos e as vítimas são omissas na procura do ressarcimento. Assim, determinou o legislador do CDC que, em tal hipótese, reverta o montante liquidado e executado pelo ente coletivo legitimado ao Fundo criado pela LACP:

Percebe-se aqui, nitidamente, que buscou o legislador inserir, dentro do instrumental coletivo disponibilizado às vítimas de eventos danosos produzidos a seus direitos individuais homogeneizados, uma maneira de, mesmo diante de sua omissão em buscar as reparações individuadas a que fariam jus, não deixar impune o responsável pela prática lesiva (VENTURI, 2000, p. 153-154).

De fato, o montante conseguido no âmbito da ação coletiva de direitos individuais homogêneos terá a mesma destinação com a reparação fluida daquele obtido na ação de defesa de direitos difusos ou coletivos. Somente a sua forma de constituição é diversa.

Assim, decorrido um ano do trânsito em julgado da sentença proferida na ação coletiva, visando a evitar que o causador do dano reste impune, a lei permite aos legitimados do art. 82 do CDC e $5^{\circ}$ da LACP promover a referida execução perante o próprio juízo da condenação, revertendo o valor a ser apurado ao fundo criado pela própria LACP.

Vale aduzir que, para a fixação do valor da fluid recovery, o juiz deve atentar para o número de pessoas que eventualmente já tenham pleiteado a indenização pelos danos ocorridos (pois quanto mais pessoas houverem se habilitado, menor o valor a ser fixado), bem como a gravidade do dano gerado, ou seja, qual o impacto que referido dano teve na sociedade, pois quanto maior o impacto social, maior o valor da indenização fluida.

Quanto ao procedimento, a liquidação da reparação fluida inicia-se com a dedução do pedido perante o juízo perante o qual se processou a ação condenatória (CDC, art. 98, parágrafo $2^{\circ}$, II). Após o regular processamento da liquidação, passa-se então a efetiva execução, que seguirá semelhante modelo preconizado na tutela dos direitos difusos e coletivos.

Adestinação da reparação fluida deve ser aplicada em proveito especificamente da classe lesada, isto é, deve voltar-se à satisfação dos interesses comuns dos indivíduos pertencentes à classe constituída pela origem comum do interesse violado ${ }^{28}$.

Por fim, quando se tratar de tutela ressarcitória específica, a execução seguira o procedimento dos arts. 461 ou 461-A do CPC (título executivo judicial) ou arts. 621 e seguintes ou ainda 632 e seguintes, todos do CPC (título executivo extrajudicial).

\section{A Execução Coletiva no Anteprojeto do Código Brasileiro de Processos Coletivos (Anteprojeto USP), em Discussão, Atualmente, no Ministério da Justiça}

Uma vez já aventado o fenômeno da ascensão das massas, do qual exsurgiu o pensamento científico de um processo voltado a tutela coletiva de interesses comuns a indivíduos socialmente considerados, cabe afirmar que há no Brasil, atualmente, forte movimento pela codificação do direito processual coletivo.

\footnotetext{
${ }^{28}$ Exemplificativamente, a fluid recovery derivada da condenação de uma empresa farmacêutica que, durante certo lapso de tempo, fabricara e vendera medicamento destinado ao tratamento de bronquite asmática, que se descobriu não possuir de fato qualquer eficácia contra tal doença, deve destinar-se ao benefício, direto e reflexo, dos portadores da referida patologia (VENTURI, 2000, p. 158).
} 
Nesse campo, o Brasil assume posição de vanguarda no tratamento dos direitos metaindividuais, revisitando os princípios processuais e a técnica processual por intermédio de normas mais abertas e flexíveis, que propiciem a efetividade do processo coletivo:

[...] a evolução doutrinária brasileira a respeito dos processos coletivos autoriza a elaboração de um verdadeiro Direito Processual Coletivo, como ramo do direito processual civil, que tem seus próprios princípios e institutos fundamentais, diversos dos do Direito Processual Individual. Os institutos da legitimação, competência, poderes e deveres do juiz e do Ministério Público, conexão, litispendência, liquidação e execução da sentença, coisa julgada, entre outros, têm feição própria nas ações coletivas que, por isso mesmo, se enquadram numa Teoria Geral dos Processos Coletivos. Diversas obras, no Brasil, já tratam do assunto. E o país, pioneiro no tratamento dos interesses e direitos transindividuais e dos individuais homogêneos, por intermédio da LACP e do CDC, tem plena capacidade para elaborar um verdadeiro Código de Processos Coletivos (BRASIL, 2007).

E quais são as vantagens desta iniciativa? Francisco Amaral (2006, p. 122-123) elucida:

A codificação apresenta vantagens, como a de simplificar o sistema jurídico, facilitando o conhecimento e aplicação do direito, permitindo ainda elaborar os princípios gerais do ordenamento que 'servirão de base para adaptar o direito à complexidade da vida real', o que explica o triunfo da codificação nos três séculos.
Com isso, a codificação torna mais evidente o objeto formal da respectiva área do Direito, de sorte a simplificar o sistema jurídico e a permitir a sua melhor compreensão. Ademais, facilita também a ordenação dos princípios expostos neste trabalho e de suas regras interpretativas no contexto de incidência da respectiva área codificada.

Logo, é de elogiar a iniciativa dos juristas que estão se dedicando ao tema da codificação, com especial destaque para a Professora Ada Pellegrini Grinover, coordenadora do Anteprojeto do Código Brasileiro de Processos Coletivos, em discussão no Ministério da Justiça e elaborado no curso de pósgraduação strictu sensu da Faculdade de Direito da Universidade de São Paulo.

Busca-se, aqui, fazer uma abordagem pontual sobre este anteprojeto no que tange especificamente aos dispositivos da tutela executiva dos direitos coletivos: art. $2^{\circ}, 15,16,17,21$, parágrafo $3^{\circ}, 26$, $27,35,36,37$ e 46.

$\mathrm{O}$ art. $2^{\circ}$, em sua alínea " $r$ "29, positiva o princípio da obrigatoriedade do cumprimento e da execução da sentença coletiva pelo Ministério Público, atualmente previsto no art. 15 da LACP. Nesse diapasão, vale ressalvar que o art. 15 do aludido anteprojeto $^{30}$ prevê apenas uma alteração quanto ao prazo, que passa de 60 para 120 dias para a promoção obrigatória da liquidação ou execução por parte do Ministério Público.

Por sua vez, o art. $16^{31}$ reproduz a possibilidade de promoção da execução provisória da sentença

${ }^{29}$ Art. $2^{\circ}$. Princípios da tutela jurisdicional coletiva - São princípios da tutela jurisdicional coletiva: r. obrigatoriedade do cumprimento e da execução da sentença;

${ }^{30}$ Art. 15. Legitimação à liquidação e execução da sentença condenatória - Na hipótese de o autor da demanda coletiva julgada procedente não promover, em 120 (cento e vinte) dias, a liquidação ou execução da sentença, deverá fazê-lo o Ministério Público, quando se tratar de interesse público relevante, facultada igual iniciativa, em todos os casos, aos demais legitimados (art. 20 deste Código).

${ }^{31}$ Art. 16. Execução definitiva e execução provisória - A execução é definitiva quando passada em julgado a sentença; e provisória, na pendência dos recursos cabíveis.

$\S 1^{\circ}$ A execução provisória corre por conta e risco do exeqüente, que responde pelos prejuízos causados ao executado, em caso de reforma da sentença recorrida.

$\S 2^{\circ}$ A execução provisória permite a prática de atos que importem em alienação do domínio ou levantamento do depósito em dinheiro.

$\S 3^{\circ}$ A pedido do executado, o tribunal pode suspender a execução provisória quando dela puder resultar lesão grave e de difícil reparação. 
coletiva, e, em regra, os recursos serão recebidos apenas no efeito devolutivo. Não se pode deixar de mencionar a crítica de Gregório Assagra de Almeida em relação ao parágrafo $1^{\circ}$ do art.:

$\mathrm{O}$ art. 16 estabelece que a execução coletiva poderá ser provisória ou definitiva; porém ele prevê, em seu parágrafo $1^{\circ}$, que ela corre por conta e risco do exequente. Essa orientação, contraria a principiologia que rege o direito processual coletivo ao inibir o comparecimento em juízo do representante adequado (ALMEIDA, 2008).

A seu turno, o art. $17^{32}$ confere disciplina adequada às custas e honorários em sede de processo coletivo, de forma a superar os impasses decorrentes da redação insuficiente constantes dos arts. 18 da LACP e 87 do CDC.
Já o art. $21^{33}$, parágrafo $3^{\circ}$, complementa o atual art. $5^{\circ}$, parágrafo $6^{\circ}$ da LACP, ao dispor que o termo de ajustamento de conduta é título executivo extrajudicial, ressalvada a hipótese de homologação judicial, quando passará a ter natureza jurídica de título executivo judicial.

$\mathrm{O}$ art. $26^{34}$ merece elogios pela sua boa técnica jurídica, pois estabelece que, em razão da indisponibilidade substancial dos direitos metaindividuais, devem prevalecer as técnicas de execução de prestação específica sobre a conversão da obrigação de reparar em perdas e danos. Nesse contexto, essa última opção somente deve ser levada a cabo quando tornar-se impossível a realização da tutela na sua forma específica. Nesse diapasão, seguem a lições de Elton Venturi (2000, p. 160):

32 Art. 17. Custas e honorários - Nas demandas coletivas de que trata este código, a sentença condenará o demandado, se vencido, nas custas, emolumentos, honorários periciais e quaisquer outras despesas, bem como em honorários de advogados, calculados sobre a condenação.

$\S 1^{\circ}$ Tratando-se de condenação a obrigação específica ou de condenação genérica, os honorários advocatícios serão fixados levando-se em consideração a vantagem para o grupo, categoria ou classe, a quantidade e qualidade do trabalho desenvolvido pelo advogado e a complexidade da causa.

$\S 2^{\circ} \mathrm{O}$ Poder Público, quando demandado e vencido, incorrerá na condenação prevista neste artigo.

$\S 3^{\circ}$ Se o legitimado for pessoa física, entidade sindical ou de fiscalização do exercício das profissões, associação civil ou fundação de direito privado, o juiz, sem prejuízo da verba da sucumbência, poderá fixar gratificação financeira, a cargo do Fundo dos Direitos Difusos e Coletivos, quando sua atuação tiver sido relevante na condução e êxito da demanda coletiva, observados na fixação os critérios de razoabilidade e modicidade.

$\S 4^{\circ}$ Os autores da demanda coletiva não adiantarão custas, emolumentos, honorários periciais e quaisquer outras despesas, nem serão condenados, salvo comprovada má-fé, em honorários de advogados, custas e despesas processuais.

$\S 5^{\circ} \mathrm{O}$ litigante de má-fé e os responsáveis pelos respectivos atos serão solidariamente condenados ao pagamento das despesas processuais, em honorários advocatícios e em até o décuplo das custas, sem prejuízo da responsabilidade por perdas e danos.

${ }^{33}$ Art. 21. Do termo de ajustamento de conduta. Preservada a indisponibilidade do bem jurídico protegido, o Ministério Público e os órgãos públicos legitimados, agindo com critérios de equilíbrio e imparcialidade, poderão tomar dos interessados compromisso de ajustamento de conduta à lei, mediante fixação de modalidades e prazos para o cumprimento das obrigações assumidas e de multas por seu descumprimento.

$\S 1^{\circ}$ Em caso de necessidade de outras diligências, os órgãos públicos legitimados poderão firmar compromisso preliminar de ajustamento de conduta.

$\S 2^{\circ}$ Quando a cominação for pecuniária, seu valor deverá ser suficiente e necessário para coibir o descumprimento da medida pactuada e poderá ser executada imediatamente, sem prejuízo da execução específica.

$\S 3^{\circ} \mathrm{O}$ termo de ajustamento de conduta terá natureza jurídica de transação, com eficácia de título executivo extrajudicial, sem prejuízo da possibilidade de homologação judicial do compromisso, hipótese em que sua eficácia será de título executivo judicial.

${ }^{34}$ Art. 26. Ação reparatória - Na ação reparatória dos danos provocados ao bem indivisivelmente considerado, sempre que possível e independentemente de pedido do autor, a condenação consistirá na prestação de obrigações específicas, destinadas à compensação do dano sofrido pelo bem jurídico afetado, nos termos do artigo 461 e parágrafos do Código de Processo Civil. $\S 1^{\circ}$ Dependendo da especificidade do bem jurídico afetado, da extensão territorial abrangida e de outras circunstâncias consideradas relevantes, o juiz poderá especificar, em decisão fundamentada, as providências a serem tomadas para a reconstituição dos bens lesados, podendo indicar a realização de atividades tendentes a minimizar a lesão ou a evitar que se repita, dentre outras que beneficiem o bem jurídico prejudicado;

$\S 2^{\circ}$ Somente quando impossível a condenação no cumprimento de obrigações específicas, o juiz condenará o réu, em decisão fundamentada, ao pagamento de indenização, independentemente de pedido do autor, a qual reverterá ao Fundo de Direitos Difusos e Coletivos, de natureza federal ou estadual, de acordo com a Justiça competente (art. 27 deste Código). 
A técnica de tutela executiva indireta, que se socorre dos meios de coerção sobre a pessoa ou sobre o patrimônio do executado, pressionando-o ao adimplemento específico da obrigação, é de extrema relevância para o processo coletivo, na execução dos direitos metaindividuais que, essencialmente, apresentam-se com caráter extrapatrimonial.

Trata-se, em última análise, da positivação do princípio da maior coincidência possível entre o direito e sua realização, conforme assevera Gregório Assagra:

Apesar da redação do art. $84, \S 1^{\circ}$, do $\mathrm{CDC}$ e do $\S 1^{\circ}$ do art. 461 do CPC, a conversão da obrigação específica em perdas e danos em relação aos direitos difusos somente poderá ocorrer se for impossível o cumprimento da obrigação específica. Os direitos difusos são direitos substancialmente indisponíveis e, por isso, não cabe ao autor a faculdade de optar, a seu bel prazer, pela conversão da obrigação específica em perdas e danos. A reparação do dano deve guiar-se pelo princípio da maior coincidência possível entre o direito e sua realização (ALMEIDA, 2008).

Seguindo esse raciocínio, o juiz deverá priorizar as medidas executivas hábeis a reparar materialmente o dano e dar cumprimento específico à obrigação. Justamente em decorrência desta premissa, o mesmo art. 26 , em seu parágrafo $1^{\circ}$, consagrou o princípio da não-taxatividade das medidas executivas.

Nesse sentido, conclui JoséMiguel Garcia Medina (apud GRINOVER; MENDES; WATANABE, 2007, p. 288): “[...] Afirma-se que neste caso se está diante de atipicidade plena, não havendo predeterminação, seja em relação às espécies de medidas que podem ser empregadas pelo juiz, seja em relação à forma e modo de aplicação da medida escolhida pelo juiz para o caso."

Merece realce, também, o art. $27^{35}$, que atribui tratamento ao Fundo de Direitos Difusos e Coletivos de forma mais ampla e aperfeiçoada que a do art. 13 da LACP.

À frente, os arts. 35, 36 e $37^{36}$ impõem disciplina

\footnotetext{
${ }^{35}$ Art. 27. Do Fundo dos Direitos Difusos e Coletivos. O Fundo será administrado por um Conselho Gestor federal ou por Conselhos Gestores estaduais, dos quais participarão necessariamente, em composição paritária, membros do Ministério Público e representantes da comunidade, sendo seus recursos destinados à realização de atividades tendentes a minimizar as lesões ou a evitar que se repitam, dentre outras que beneficiem os bens jurídicos prejudicados, bem como a antecipar os custos das perícias necessárias à defesa dos direitos ou interesses difusos, coletivos e individuais homogêneos e a custear o prêmio previsto no parágrafo $3^{\circ}$ do artigo 17 .

$\S 1^{\circ}$ Além da indenização oriunda da sentença condenatória, prevista no parágrafo 20 do artigo 26 , e da execução pelos danos globalmente causados, de que trata o parágrafo $3^{\circ}$ do artigo 36 , ambos deste Código, constitui receita do Fundo, dentre outras, o produto da arrecadação de multas, inclusive as decorrentes do descumprimento de compromissos de ajustamento de conduta. $\S 2^{\circ} \mathrm{O}$ representante legal do Fundo, considerado funcionário público para efeitos legais, responderá por sua atuação nas esferas administrativa, penal e civil.

$\S 3^{\circ} \mathrm{O}$ Fundo será notificado da propositura de toda ação coletiva e sobre as decisões mais importantes do processo, podendo nele intervir em qualquer tempo e grau de jurisdição na função de "amicus curiae".

$\S 4^{\circ} \mathrm{O}$ Fundo manterá e divulgará registros que especifiquem a origem e a destinação dos recursos e indicará a variedade dos bens jurídicos a serem tutelados e seu âmbito regional;

$\S 5^{\circ}$ Semestralmente, o Fundo dará publicidade às suas demonstrações financeiras e atividades desenvolvidas.

${ }^{36}$ Art. 35. Liquidação e execução coletivas - Se possível, a liquidação e a execução serão coletivas, sendo promovidas por qualquer dos legitimados do artigo 20 deste Código.

Art. 36. Liquidação e execução pelos danos globalmente causados - Decorrido o prazo de um ano sem habilitação de interessados em número compatível com a gravidade do dano, poderão os legitimados do artigo 20 deste Código promover a liquidação e execução coletiva da indenização devida pelos danos causados.

$\S 1^{\circ} \mathrm{Na}$ fluência do prazo previsto no caput deste artigo a prescrição não correrá.

$\S 2^{\circ} \mathrm{O}$ valor da indenização será fixado de acordo com o dano globalmente causado, que poderá ser demonstrado por meio de prova pré-constituída ou, não sendo possível, mediante liquidação.

$\S 3^{\circ} \mathrm{O}$ produto da indenização reverterá ao Fundo (art. 27 deste Código), que o utilizará para finalidades conexas à proteção do grupo, categoria ou classe beneficiados pela sentença.

$\S 4^{\circ}$ Enquanto não se consumar a prescrição da pretensão individual, fica assegurado o direito de exigir o pagamento pelo Fundo, limitado o total das condenações ao valor que lhe foi recolhido.

Art. 37. Concurso de créditos - Em caso de concurso de créditos decorrentes de condenação de que trata o artigo 26 deste Código
} 
própria à tutela executiva dos direitos e interesses individuais homogêneos, reproduzindo, em linhas gerais, a orientação já constante no CDC (arts. 96 a 100).

De forma pontual, esses são os dispositivos que abordam a execução coletiva na proposta apresentada no anteprojeto da USP. Afora alguns melhoramentos, como a disposição expressa da principiologia a reger o direito processual coletivo, de nossa parte entendemos que, no caso da execução coletiva, a disciplina mencionada ainda é muito tímida e insuficiente para libertar o processo coletivo das amarras individualistas do $\mathrm{CPC}^{37}$. Sequer há um capítulo reservado ao processo de execução para os títulos executivos extrajudiciais (TAC e outros) ou para prever as formas de exercício de defesa no rito executório.

Impende dizer, ainda, que um Código Brasileiro de Direito Processual Coletivo deverá ter um corpo maior, uma vez que 52 artigos são insuficientes para abranger adequadamente assuntos de extrema importância social como meio ambiente e consumidor.

Logo, espera-se que o aludido anteprojeto seja objeto de debates nacionais para seu aperfeiçoamento e complementação, eis que sua possível aprovação consistirá em momento histórico na evolução do direito processual brasileiro e, quiçá, mundial.

\section{Conclusão}

Inicialmente, cumpre frisar que o tema proposto ainda será objeto de muitas discussões, especialmente em razão do fortalecimento do movimento de codificação do processo coletivo no ordenamento jurídico pátrio.
Nada mais natural, uma vez que é certo que vivemos numa era que não é apenas "dos direitos", como assinala Bobbio, mas, em uma afirmação realista, um momento marcado pela dramática tentativa de torná-los eficazes, atuantes, enfim, úteis aos indivíduos e à sociedade à qual nos inserimos.

Nesse ínterim, é de se destacar que o direito brasileiro, não alheio à nova realidade sócioeconômica que impõe, cada vez mais, a massificação dos bens e do consumo, tratou, gradativamente, de conceder tutela preventiva e repressiva às lesões ocasionadas a uma série de direitos não titularizados por pessoas individualmente consideradas.

A despeito disto, o microssistema da tutela coletiva (CPC, CDC e LACP) ainda possui sérios vácuos a serem preenchidos, principalmente em relação à execução coletiva. Viu-se que o CDC até chega a conferir, de modo insuficiente, tratamento especificamente direcionado aos direitos individuais homogêneos (art. 95 a 100). Todavia, em relação aos direitos difusos e coletivos em sentido estrito a situação é de completo vazio legislativo.

Por conseguinte, a busca pelo aperfeiçoamento do ordenamento deve ser pautada por algumas premissas ou conclusões.

O CPC vigente é marcado por sua índole individualista e não apresenta soluções satisfatórias para a tutela executiva metaindividual, de sorte que sua aplicabilidade ao processos coletivos é limitada e condicionada.

Em face disto e da tendência de massificação dos conflitos no mundo contemporâneo, a iniciativa do movimento de codificação de processo coletivo é louvável. Entretanto, percebeu-se que o Anteprojeto do Código Brasileiro de Processos Coletivos ainda

e de indenizações pelos prejuízos individuais resultantes do mesmo evento danoso, estas terão preferência no pagamento.

Parágrafo único. Para efeito do disposto neste artigo, a destinação da importância a ser recolhida ao Fundo ficará sustada enquanto pendentes de decisão de recurso ordinário as ações de indenização pelos danos individuais, salvo na hipótese de o patrimônio do devedor ser manifestamente suficiente para responder pela integralidade das dívidas.

${ }^{37}$ Nessa linha: "O anteprojeto (art. 49) manda aplicar subsidiariamente o CPC sem estabelecer, contudo, regras limitadoras dessa aplicabilidade. O CPC é um código liberal individualista e sua aplicabilidade, sem a limitação necessária, ao processo coletivo, poderá acarretar graves danos À proteção dos interesses e direitos massificados fundamentais (ALMEIDA, 2007, p. 113). 
não confiou disciplina adequada a um tema tão complexo como a execução coletiva, a qual ainda deverá ser alvo de muitos debates.

Diante desta carência legislativa e, ainda, considerando o status constitucional de direitos fundamentais (Título II, Capítulo I da Carta Magna) atribuído aos direitos coletivos, os princípios constitucionais fundamentais e os princípios do processo coletivo (como por exemplo, o da máxima amplitude da tutela jurisdicional coletiva e da atipicidade das medidas executivas) constitutem parâmetros sob os quais deve ser orientada a prestação jurisdicional no rito executório.

Por fim, é importante que a tomada de medidas no sentido de criação de disciplina própria e adequada para a execução dos direitos metaindividuais se preocupe em tratar separadamente e de forma diferenciada as categorias dos direitos coletivos, inclusive no aspecto procedimental, eis que o direito sem a efetividade concreta é direito morto, já que desprovido do elemento essencial para conduzir as relações sociais.

\section{Referências}

ALMEIDA, Gregório Assagra. Codificação do direito processual coletivo brasileiro: análise crítica das propostas existentes e diretrizes para uma nova proposta de codificação. Belo Horizonte: Del Rey, 2007.

ALMEIDA, Gregório Assagra de. Direito processual coletivo: um novo ramo do direito processual (princípios, regras interpretativas e a problemática de sua interpretação e aplicação). São Paulo: SARAIVA, 2003.

ALMEIDA, Gregório Assagra de. Execução coletiva em relação aos direitos difusos, coletivos e individuais homogêneos: algumas considerações reflexivas. Jus Navigandi, Teresina, ano 13, n. 1956, 8 nov. 2008. Disponível em: $<$ http://jus2.uol.com.br/doutrina/texto. asp?id=11951 $>$. Acesso em: 16 mar. 2009.

ALVIM, Arruda; ALVIM, Thereza; ALVIM, Eduardo Arruda; SOUZA, James J. Marins de. Código do consumidor comentado. São Paulo: RT, 1991.

AMARAL, Francisco. Direito civil: introdução. 6. ed.. Rio de Janeiro: RENOVAR, 2006. (De acordo com o novo Código Civil)
ARAÚJO, Luiz Alberto David; NUNES JÚNIOR, Vidal Serrano. Curso de direito constitucional. 9. ed. São Paulo: SARAIVA, 2005.

BOBBIO, Norberto. A era dos direitos. Rio de Janeiro: Campus, 1992.

BRASIL. Lei no 7.347, de 24 de julho de 1985. Disciplina a ação civil pública de responsabilidade por danos causados ao meio-ambiente, ao consumidor, a bens e direitos de valor artístico, estético, histórico, turístico e paisagístico (VETADO) e dá outras providências. Disponível em: <http://www.planalto.gov.br/ccivil_03/ leis/17347compilada.htm>. Acesso em: 10 mar. 2009.

BRASIL. Lei $n^{\circ} 8.078$, de 11 de setembro de 1990. Dispõe sobre a proteção do consumidor e dá outras providências. Disponível em: < http://www.planalto.gov.br/ccivil_03/ leis/18078.htm>. Acesso em: 10 mar. 2009.

BRASIL. Ministério da Justiça. Anteprojeto de código brasileiro de processos coletivos exposição de motivos. 2007. Disponivel em: < http://www.projustica.com.br/ viewcontent.php? $\mathrm{m}=$ mainlist\&cod=79>. Acesso em: $<10$ mar. 2009.

BRASIL. Superior Tribunal de Justiça. Recurso Especial $n^{\circ} 933.002$ - RJ (2007/0047268-0). Recorrente: Colégio Pedro II. Recorrido: Ministério Público Federal. Relator: Ministro Castro Meira. Rio de Janeiro, 2007. Disponível em: <http://www.jusbrasil.com.br/filedown/dev2/files/ JUS2/STJ/IT/RESP_933002_RJ_1260394022104.pdf>. Acesso em: 16 mar. 2009.

CAPPELLETTI, Mauro. Acesso a justiça. Porto Alegre: SaFe, 1975.

DINAMARCO, Cândido Rangel. As três figuras da liquidação de sentença. In: WAMBIER, Luiz Rodrigues. Atualidades sobre a liquidação de sentença. São Paulo: RT, 1997.

FACHIN, Zulmar. Curso de direito constitucional. 3. ed. São Paulo: Método, 2008.

FIORILLO, Celso Antônio Pacheco. Os sindicatos e a defesa dos interesses difusos no direito processual civil brasileiro. São Paulo: Revista dos Tribunais, 1995.

GAJARDONI, Fernando. Principio da participação no processo coletivo. Disponívelem: $<\mathrm{http}: / /$ www.lfg.com.br/ public_html/article.php?story=20090506092026312>. Acesso em: 10 maio 2009.

GIDI, Antônio. Coisa julgada e litispendência em ações coletivas. São Paulo: Saraiva, 1995.

GONÇALVES, Marcus Vinícius Rios. Tutela de interesses difusos e coletivos. 3. ed. São Paulo: Saraiva, 2007. 
GRINOVER, Ada Pellegrini. Código brasileiro de defesa do consumidor comentado pelos autores do anteprojeto. 4. ed. São Paulo: Forense Universitária, 1995.

GRINOVER, Ada Pellegrini. Teoria processual da constituição. São Paulo: Celso Bastos, 2000.

GRINOVER, Ada Pellegrini; MENDES, Aluisio Gonçalves de Castro; WATANABE, Kazuo (Coord.). Direito processual coletivo e o anteprojeto de Código Brasileiro de Processo Coletivos. São Paulo: Revista dos Tribunais, 2007.

LEITE, Carlos Henrique Bezerra. Curso de direito processual do trabalho. 7. ed. São Paulo: LTr, 2009.

LEITE, Emília Matilde Araújo de Vasconcelos. Anotações acerca da tutela coletiva dos direitos difusos, coletivos e individuais homogêneos e da sua sistematização. Disponível em: <http://www.jfrn.gov.br/ doutrina/doutrina224.doc>. Acesso em: 10 mar. 2009.

MACHADO, Paulo Affonso Leme. Direito ambiental. 7. ed. Malheiros: São Paulo, 1999.

MANCUSO, Rodolfo de Camargo. Ação Popular. São Paulo: RT, 1994a.

MANCUSO, Rodolfo de Camargo. Manual do consumidor em juizo. São Paulo: Saraiva, 1994b.

MANCUSO, Rodolfo de Camargo. Interesses difusos e coletivos. Revista de Direito do Consumidor, São Paulo, v. 1, n. 22, 1997.

MAZZILLI, Hugo Nigro. A defesa dos interesses difusos em juizo: meio ambiente, consumidor e outros interesses difusos e coletivos. São Paulo: Saraiva, 2008.

MOREIRA, José Carlos Barbosa Ações coletivas na Constituição Federal de 1988. Revista de Processo, v. 16, n. 61, p. 187-200, 1991.

MOREIRA, José Carlos Barbosa. A proteção jurídica dos interesses coletivos. In: Temas de direito processual: terceira série. São Paulo: Saraiva, 1977.

MOREIRA, José Carlos Barbosa. A proteção jurisdicional dos interesses coletivos ou difusos. In: . A tutela dos interesses difusos. São Paulo: Max Limonad, 1984. p. 102.

NERY JÚNIOR, Nelson. Princípios do processo civil na Constituição Federal. São Paulo, RT: 2004.

SILVA, Rosana Ribeiro. A coisa julgada na defesa dos interesses difusos e coletivos. 2000. Disponível em: $<$ http://jus.uol.com.br/revista/texto/815/a-coisa-julgadana-defesa-dos-interesses-difusos-e-coletivos $>$. Acesso em: 16 mar. 2009.

SOUZA, Carolina Botti de. A coisa julgada nas ações coletivas. 2000. Trabalho de Conclusão de Curso. Graduação (Graduação em Direito) - Universidade Estadual de Londrina, Londrina.

TAVARES, André Ramos. Curso de direito constitucional. 5. ed. São Paulo: Saraiva, 2007.

VENTURI, Elton. Execução da tutela coletiva. Rio de Janeiro: Malheiros, 2000.

VIGLIAR, José Marcelo Menezes. Tutela jurisdicional coletiva. São Paulo: Atlas, 1998.

WATANABE, Kazuo. Demandas coletivas e os problemas emergentes da práxis forense. Revista do Processo, São Paulo, n. 67, p. 15-25, 1992.

WATANABE, Kazuo. Demandas Coletivas e os problemas emergentes da práxis forense. In: TEIXEIRA, Saĺvio de Figueiredo. As garantias do cidadão na justiça. São Paulo: Saraiva, 1993.

WATANABE, Kazuo. Código brasileiro de defesa do consumidor: comentado pelos autores do anteprojeto. 6 . ed. Rio de Janeiro: Forense, 1999.

YARSHELL, Flávio Luiz. Observações a propósito da liquidação na tutela dos direitos individuais homogêneos. In: WAMBIER, Teresa Arruda Alvim (Org.). Atualidades sobre liquidação de sentença. São Paulo: Revista dos Tribunais, 1997. p. 151-166.

Recebido em: abril 2010

Aceito em: julho 2010 
